OPEN ACCESS

Edited by:

Jonathan Richir,

Fonds National de la Recherche

Scientifique (FNRS), Belgium

Reviewed by:

Luigi Piazzi,

University of Sassari, Italy

José Luis Sánchez Lizaso,

University of Alicante, Spain

Enric Ballesteros,

Spanish National Research Council,

Spain

Franck Lagarde,

Institut Français de Recherche pour

l'Exploitation de la Mer (IFREMER),

France

*Correspondence:

Charles-François Boudouresque charles.boudouresque@ mio.osupytheas.fr

Specialty section: This article was submitted to Marine Fisheries, Aquaculture and Living Resources,

a section of the journal Frontiers in Marine Science

Received: 12 December 2019 Accepted: 19 March 2020 Published: 17 April 2020

Citation:

Boudouresque $C-F$, Blanfuné $A$, Pergent $G$, Pergent-Martini $C$,

Perret-Boudouresque $M$ and

Thibaut T (2020) Impacts of Marine and Lagoon Aquaculture on Macrophytes in Mediterranean

Benthic Ecosystems.

Front. Mar. Sci. 7:218.

doi: 10.3389/fmars.2020.00218

\section{Impacts of Marine and Lagoon Aquaculture on Macrophytes in Mediterranean Benthic Ecosystems}

\author{
Charles-François Boudouresque ${ }^{*}$, Aurélie Blanfuné1, Gérard Pergent ${ }^{2}$, \\ Christine Pergent-Martini' ${ }^{2}$, Michèle Perret-Boudouresque ${ }^{1}$ and Thierry Thibaut $^{1}$
}

\footnotetext{
'Aix Marseille Univ., Université de Toulon, CNRS, IRD, MIO UM 110, Marseille, France, ${ }^{2}$ Università di Corsica Pasquale Paoli, Corte, France
}

The direct and indirect impact of fish farms, shellfish aquaculture, and extensive forms of aquaculture such as seeding of juvenile sea urchins, on macrophytes (seaweeds and seagrasses), is reviewed in Mediterranean benthic ecosystems. Fish farms constitute a source of organic matter and nutrients (food and fecal pellets) that causes the extirpation of Posidonia oceanica seagrass meadows beneath and near to farm facilities. In addition to direct effects, the nitrogen enrichment of macrophytes tissues increases the grazing pressure by herbivorous fishes and sea urchins. In some cases, the impact can continue to increase several years after the cessation of farming activities. Natural restoration of extirpated seagrass meadows is generally unlikely at the human time scale. Shellfish aquaculture is the cause of the main flow of introduced macrophytes in the Mediterranean; the main vector is the importation of oyster spat from Japan and Korea. North-eastern Pacific seaweeds are now the dominant biotic component of some Mediterranean lagoons (e.g., Thau, Mar Piccolo, and Venice lagoons). In addition to direct effects, mussel aquaculture can constitute a source of larvae that flow with currents, the adults of which can overwhelm seaweed forests (e.g., Carpodesmia mediterranea). Shellfish aquaculture is also a source of fecal pellets, resulting in changes in bottom macrophytes, and a vector of diseases of metazoans, the extirpation of which may change the functioning of recipient macrophyte ecosystems. The edible sea urchin Paracentrotus lividus is sometimes erroneously considered as in decline due to overharvesting. However, its abundance in the second half of the 20th century was probably a consequence of human impact (overfishing of its predatory fish, organic pollution. This man-induced proliferation resulted in the extirpation of seaweed forests (e.g., Carpodesmia spp., Treptacantha spp. - formerly Cystoseira spp. - Sargassum spp.; many species are endemic), which play a key role in Mediterranean coastal ecosystems. Therefore, the attempts to restore sea urchin abundance, via seeding of juveniles from hatcheries, has further artificialized the habitats rather than contributing to the restoration of natural ecosystems. Good practices guidelines are proposed aimed at minimizing the impact of aquaculture on macrophytes.

Keywords: aquaculture, fish farms, macrophytes, mediterranean, Paracentrotus lividus, shellfish culture 


\section{INTRODUCTION}

The aquaculture of marine organisms has undergone a spectacular development in the Mediterranean since the beginning of the 20th century, particularly since the 1980s, especially shellfish culture in the western basin and fish farming in the eastern basin (Charbonnier, 1990; Belias and Dassenakis, 2002; Basurco and Lovatelli, 2003; Grigorakis and Rigos, 2011; Rountos et al., 2012; Massa et al., 2017).

Until then, it consisted only of very extensive forms of aquaculture, such as valliculture, in the northern Adriatic and Tyrrhenian seas (Italy). Valliculture, the origin of which dates back at least to the 15th century, and is probably even more ancient, is a practice consisting in the exploitation of the natural seasonal migrations of some fish species (mainly gray mullets) from the sea into coastal lagoons, by keeping fish in enclosures ("valli," in Italian), preventing the fish from returning to the sea, then capturing them several years later during their descent to the sea (Lumare, 1983). Aquaculture of brackish species might have been known in the Egypt of the pharaohs, in manmade pools in the Nile Delta (Basurco and Lovatelli, 2003; Soliman and Yacout, 2016).

Modern forms of aquaculture, in the Mediterranean Sea, range from the very extensive ones, such as the seeding of juveniles of the sea urchin Paracentrotus lividus, to more intensive methods, such as the fish farms where fish located at a high level in the food webs are reared with artificial food. Here, we review the more or less worrying impact of aquaculture on Mediterranean species of macrophytes and the ecosystems for which they may be an "ordinary" contributor, a key species or an ecosystem engineer. The aim is to present a synthesis of the data dispersed in a large number of publications, by considering both direct and indirect effects of aquaculture, and to propose good practices guidelines aimed at minimizing the impact of aquaculture on macrophytes. In this review, we have taken into all the published references, with the exception of redundant data and gray literature and the Mediterranean Sea. It is important to underline that, despite the peculiarities of the Mediterranean Sea (Lejeusne et al., 2010), the conclusions we draw from the Mediterranean are largely generalizable to the world ocean (e.g., Yokoyama et al., 1997; Boyra et al., 2004; Loya et al., 2004; Hall-Spencer et al., 2006; Weitzman et al., 2019; but see Walls et al., 2017).

The notion of macrophytes actually encompasses a polyphyletic complex (Boudouresque, 2015; Boudouresque et al., 2015a). Macrophytes, or multicellular photosynthetic organisms, belong to both the prokaryotes (namely Cyanobacteria) and the eukaryotes. Within the eukaryotes, macrophytes belong to four taxa, very far apart in the phylogenetic tree of eukaryotes. (i) The Ulvophyceae (phylum Chlorobionta, subkingdom Viridiplantae) are part of what are popularly called "green algae." (ii) The Magnoliophyta (phylum Streptobionta, subkingdom Viridiplantae) are what is popularly called "flowering plants"; some terrestrial flowering plants which had returned to the sea, 100-60 Ma ago, are the ancestors of e.g., modern Posidonia, Cymodocea, and Zostera (Kuo et al., 2000; Orth et al., 2006). (iii) The Florideophyceae (subkingdom Rhodobionta) are part of what are popularily called "red algae." Ulvophyceae,
Magnoliophyta and Florideophyceae belong to the kingdom Archaeplastida. (iv) Finally, the Phaeophyceae belong to the phylum Ochrophyta (= Chromobionta), within the kingdom Stramenopiles (= Heterokonta); they are popularly called "brown algae."

The Mediterranean is a semi-enclosed sea. It is bordered on its southern coast (from Egypt to Morocco) by arid regions and the contribution of its rivers and groundwater discharge does not compensate for evaporation, so that the water deficit is $0.5-1.0$ $\mathrm{m} \mathrm{a}^{-1}$ (Millot and Taupier-Letage, 2005; Rodellas et al., 2015). Last but not least, the construction of the Aswan High Dam in Egypt, completed in 1970, has nearly dried up the Nile River (at its mouth), formerly the most important Mediterranean river, very little of whose waters now reach the Mediterranean Sea (Sharaf and El Din, 1977; Stanley, 1993; Abu-Zeid and El-Shibini, 1997; Khadr, 2003). This deficit in water of the Mediterranean Sea is offset by the entry of Atlantic water through the Straits of Gibraltar (Bethoux, 1979; Farmer and Armi, 1988; Bethoux and Gentili, 1998; Millot and Taupier-Letage, 2005). Despite the relatively nutrient-rich supply of Atlantic water, the low influx of rivers is responsible for the fact that the Mediterranean is an oligotrophic or highly oligotrophic sea; it is also characterized by high environmental variability and by steep gradients, e.g., of salinity, temperature and stratification, which all tend to increase eastwards, within the relatively restricted Mediterranean area (Bethoux et al., 1999; Turley, 1999; Lejeusne et al., 2010; Rodellas et al., 2015; Massa et al., 2017). The Mediterranean Sea has been compared to a giant microcosm of the world's ocean, or to a "miniature ocean" (Bethoux et al., 1999; Lejeusne et al., 2010). Finally, the opening up of the Suez Canal, in 1869, which joins the Red Sea and the Mediterranean, created a real "highway" for the arrival of exotic species in this region, and was the major modern biogeographical event in the world ocean (Por, 1978, 1990; Boudouresque, 1999b).

\section{FISH FARMS}

Mediterranean marine fish farming was initially land-based. Since the 1990s, it was transferred to floating cages at sea (Grigorakis and Rigos, 2011; Massa et al., 2017). In 2013, it was dominated by two main species: the European seabass Dicentrarchus labrax with $\sim 161,000 \mathrm{t} \mathrm{a}^{-1}$ (tones = metric tons, per year) and the gilthead seabream Sparus aurata with $\sim 135,000$ $\mathrm{t} \mathrm{a}^{-1}$ (Belias and Dassenakis, 2002; Massa et al., 2017). Farming of these species involves a first phase taking place in a land-based hatchery, then the moving of juvenile fish to floating cages at sea. The Atlantic bluefin tuna Thunnus thynnus is farmed by a different type of process, as it is based on the capture of wild specimens $(8-10 \mathrm{~kg})$ which are then grown in cages to market size of at least $30 \mathrm{~kg}$ (Kružić, 2008; Mylonas et al., 2010; Grigorakis and Rigos, 2011). Several other finfish species are reared in the Mediterranean, such as the meager Argyrosomus regius and the sharpsnout sea bream Diplodus puntazzo, the latter still at an experimental stage (Stipa and Angelini, 2005; Sánchez-García et al., 2014). Although it is a brackish and freshwater form of aquaculture, it is relevant to also mention the most important 
Mediterranean aquaculture industry, that of the Nile tilapia Oreochromis niloticus; in 2012, for Egypt alone, the production amounted to $\sim 769,000 \mathrm{t}$ (Soliman and Yacout, 2016).

Land-based farm wastewater affects the isotopic composition, and mainly $\delta^{15} \mathrm{~N}$ values, of benthic macrophytes; the impact of a fairly small farm on the seagrass Posidonia oceanica and the red alga Sphaerococcus coronopifolius was detected at a distance of $500 \mathrm{~m}$ from the outfall (Vizzini and Mazzola, 2004). However, the effects can be easily avoided by using land-based wastewater treatment. Off-shore fish farms are also responsible for elevated $\delta^{15} \mathrm{~N}$ signature in leaf tissues and epibionts of a deep P. oceanica meadow, up to $3 \mathrm{~km}$ from the cages (Ruiz et al., 2010).

Offshore fish farms, with fish reared in floating cages, which today represent the bulk of marine fish farming, can affect the marine environment, directly and indirectly, in several ways, through (i) the release of nutrients (nitrogen and phosphorus), (ii) the release of particulate organic carbon (e.g., fecal pellets and uneaten feed) and (iii) chemicals (e.g., copper in antifouling treatments and drugs for disease treatments). The effects vary according to the production system, site characteristics, hydrodynamics and movements at the bottom of the water column, the species farmed, the feed used and the sensitivity of the receiving ecosystem (Sarà et al., 2006; Holmer et al., 2008; Marino, 2011; Massa et al., 2017).

Many environmental requirements for coastal fish farming (e.g., good water quality and water renewal) correspond almost exactly to the habitat preferences of $P$. oceanica; as a result, a number of fish farms are placed over or very near $P$. oceanica meadows (Holmer et al., 2008). Studies on fish cage aquaculture located over Posidonia oceanica seagrass meadows have shown a very strong impact on this ecosystem of paramount importance for Mediterranean coastal areas (Pergent-Martini et al., 2006; Boudouresque et al., 2009, 2012, 2016; Grigorakis and Rigos, 2011; Giakoumi et al., 2015; Kletou et al., 2018). The P. oceanica ecosystem thrives between the sea level and 30-40 m depth, in the infralittoral zone (Molinier and Picard, 1952; Boudouresque and Meinesz, 1982; Boudouresque et al., 2012); for Mediterranean biotic zones and habitats, see Pérès and Picard (1964) and Pérès (1982). (i) There is a decrease in light availability under facilities, due to both increased turbidity (including possible phytoplankton enhancement) and the shadow of the cages: $38 \%$ of the bottom light is lost beneath the cages in the Gulf of Ajaccio (Corsica). However, the amount of light is still higher than the compensation irradiance level of $P$. oceanica. Therefore, this factor alone cannot explain the regression of the meadow observed (Verneau et al., 1995; Delgado et al., 1997; Mendez et al., 1997; Pergent et al., 1999; Ruiz and Romero, 2001; Ruiz et al., 2001). This statement may be right for shallow meadows, but not for deeper meadows, which are light limited (Romero et al., 1998). According to Puhr and Pikelj (2012), light availability is the main factor that controls seagrass distribution at fish farm locations. Light available for $P$. oceanica photosynthesis is also reduced by the high epibiont coating caused by nutrient enrichment (Cancemi et al., 2000, 2003; see below). (ii) Because of the input of fecal pellets and uneaten food, the sediment is enriched in organic matter, which alter its physical and chemical characteristics and enhances anoxic conditions and sulfate reduction processes
(Pergent et al., 1999; Ruiz et al., 2001; Cancemi et al., 2003; Holmer et al., 2003, 2008; Boudouresque et al., 2012; Weitzman et al., 2019). This factor emerges as one of the main drivers of benthic deterioration, via e.g., sediment anoxia (Holmer et al., 2008). (iii) The water is enriched in nutrients, especially ammonium (Holmer et al., 2008; Grigorakis and Rigos, 2011), which may enhance phytoplankton development but especially fosters the growth of the $P$. oceanica leaves and increases the biomass of their epibionts. It is worth noting that the effect of nutrient enrichment is different according to depth (Romero et al., 1998). The maximum increase in epibiont biomass does not occur beneath the cages, but at a distance of between 20 and $80 \mathrm{~m}$ at Figari (Corsica), which may be explained by the large quantities of copper introduced with the fish food and/or antifouling chemicals used for the nets (Mendez et al., 1997; Pergent et al., 1999; Dimech et al., 2000a; Holmer et al., 2003; Pergent-Martini et al., 2006; Kružić, 2008). (iv) In contrast with the increase or decrease in leaf growth and epibiont biomass, the vertical growth of rhizomes abruptly declines by about twofold following the onset of fish farm operations; this decline is perceptible up to $400 \mathrm{~m}$ from the farm (Marbà et al., 2006; Holmer et al., 2008). (v) The concentration of trace metals, such as copper and zinc in rhizomes of $P$. oceanica, increases near the facilities. They derive from uneaten feed, fish excreta and antifouling chemicals used to prevent development of fouling organisms on the cages (Pergent et al., 1999; Basaran et al., 2010; Grigorakis and Rigos, 2011). (vi) The epibiontic cover of the leaves, together with the high nitrogen content of leaf tissues and epibionts, are attractive for herbivorous species, such as the teleost Sarpa salpa and the sea urchin Paracentrotus lividus. Sea urchins are actually more abundant in the vicinity of cages. As a result, the grazing of leaves is higher beneath and near facilities than at control sites (Mendez et al., 1997; Pergent et al., 1999; Ruiz et al., 2001; Pérez et al., 2008; Prado et al., 2008; Balata et al., 2010; Rountos et al., 2012). (vii) Fish populations are increased, both in biomass, number of individuals and sometimes point species diversity (Verneau et al., 1995; Machias et al., 2004, 2005). In the Gulf of Ajaccio, biomass and density of fish are increased

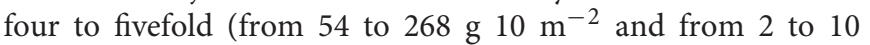
individuals $10 \mathrm{~m}^{-2}$, respectively); the most successful species are e.g., stripped red mullet Mullus surmuletus, bogue Boops boops and barracuda Sphyraena sphyraena. The trophic structure of fish populations is also changed, with fewer invertebrate consumers and more omnivorous species (Verneau et al., 1995). In Malta, benthic invertebrates (decapods, mollusks and echinoderms) also exhibit an increase in abundance of individuals and point species diversity at intermediate distances $(40-160 \mathrm{~m})$ from the cages (Dimech et al., 2000b, 2002). (viii) Beneath the cages and in the adjacent area, there is an overall regression of the meadow: the shoot density conspicuously declines and extensive areas of dead matte appear (Figure 1; Verneau et al., 1995; Delgado et al., 1997; Dimech et al., 2000a; Cancemi et al., 2003; PergentMartini et al., 2006; Holmer et al., 2008; Kružić, 2008; Pérez et al., 2008; Boudouresque et al., 2012; Kletou et al., 2018). Matte is the structure built by living and dead rhizomes and by the sediment that fills the interstices; because of the very slow or even the absence of degradation of dead rhizomes and roots 


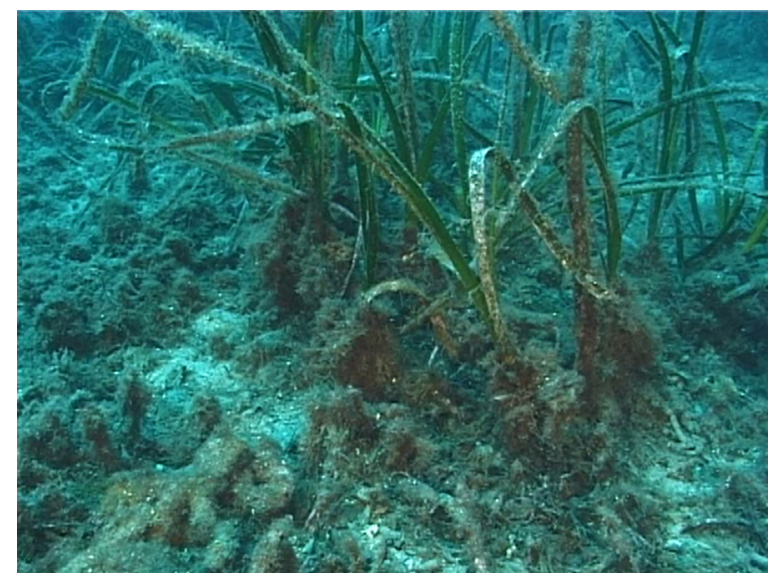

FIGURE 1 | A Posidonia oceanica meadow severely degraded under and in the vicinity of a fish farm. Bay of Calvi (Corsica). Photo @ Gérard Pergent.

within the matte, the matte can persist for at least millennia (Molinier and Picard, 1952; Boudouresque and Meinesz, 1982; Boudouresque et al., 2012, 2016).

The case of the El Hornillo fish farm (Murcia region, Spain), a medium scale farm (up to 700-800 metric tons of fish per year) is particularly instructive (Figure 2). Fish farming began in 1989. Since the onset of fish farming, 11 ha (28\%) of the former $P$. oceanica meadow have been rapidly and completely lost and 10 ha $(25 \%)$ significantly degraded, with a decline in shoot density; the affected area (a radius of $300 \mathrm{~m}$ from the fish farm perimeter) therefore amounts to about $53 \%$ of the former meadow, and 7 times the fish farm area (Ruiz-Fernandez, 2000; Ruiz et al., 2001).

Another case is also instructive, that of the Fornells Bay (Menorca Island, Spain) fish farm. It was established in 1986, and its activity ceased in 1991. However, the regression of the $P$. oceanica meadow, which quickly began as soon as the farm came into operation, continued for at least three years; the persistence of the seagrass decline could be due to the excess of organic matter remaining in the sediment (Delgado et al., 1999). Interestingly, in Cyprus, close to the upper thermal limit of $P$. oceanica, fish farms initially located over a $P$. oceanica meadow were relocated offshore; three to five years later, not only had the regression ceased, but the margin of the meadow had progressed, which illustrates an important management success story (Kletou et al., 2018).

Similar conclusions can be drawn for coastal detritic bottoms, e.g., maërl beds, which are dominated by calcareous Rhodobionta, in the circalittoral zone, deeper than the infralittoral zone (Sanz-Lázaro et al., 2011; Aguado-Giménez and Ruiz-Fernández, 2012; Massa et al., 2017 and references therein); below experimental fish cages, the maërl community was almost completely buried; dead and blackened rhodoliths were covered by a thin layer of sediment and only a few individuals of Gracilaria cylindrica, Lithophyllum racemus, Meredithia microphylla (Rhodobionta) and Fabellia petiolata (Ulvophyceae) remained alive (Aguado-Giménez and RuizFernández, 2012). In a coralligenous ecosystem, from 30 to $40 \mathrm{~m}$
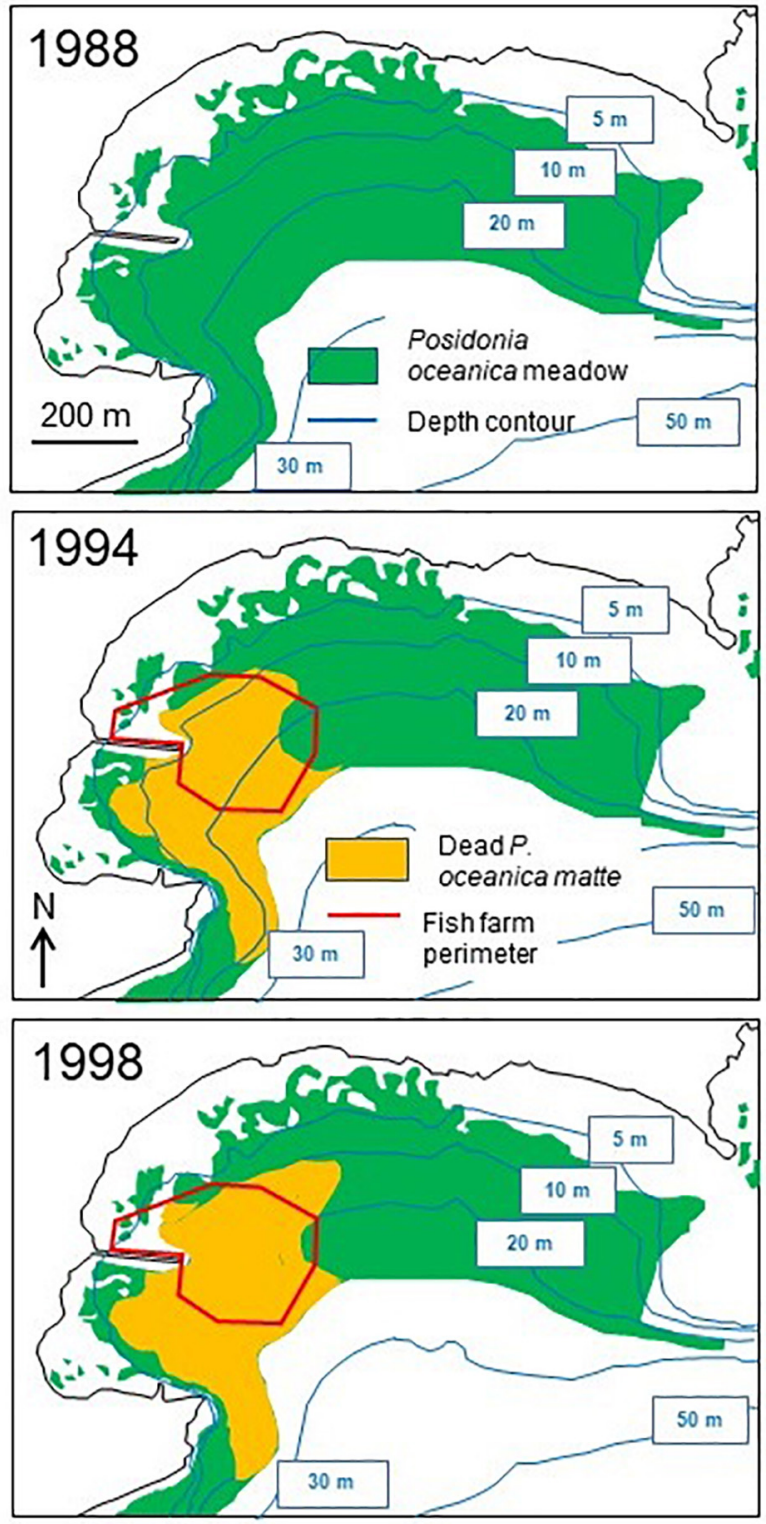

FIGURE 2 | Distribution of Posidonia oceanica meadow in 1988, 1994, and 1998 in El Hornillo Bay (Murcia, Spain). Only the complete mortality off (area of dead matte) has been mapped. Original drawing, after Ruiz-Fernandez (2000) and Ruiz et al. (2001) data.

of depth, at about $30 \mathrm{~m}$ of cages, there is a decrease in $\beta$ - diversity, encrusting Corallinales, erect Rhodobionta, Dictyotales, Fucales (Phaeophyceae) and Halimeda tuna (Ulvophyceae) and an increase in Peyssonnelia spp. (Rhodobionta) and algal turfs (Piazzi et al., 2019). Unfortunately, most authors focus on the impact of fish farming on $P$. oceanica meadows, but pay little attention to other macrophyte assemblages. For example, in El Hornillo Bay (Spain), Ruiz et al. (2001) briefly mention other benthic communities, e.g., the presence of the seagrass Cymodocea nodosa on shallow sandy bottoms, 
but the possible impact of the fish farm was not addressed. In Fornells Bay (Menorca Island, Spain), C. nodosa was less affected than P. oceanica (Delgado et al., 1997). On artificial hard substrate, the fouling community, initially dominated by seaweeds, was transformed, in 6 months, into a community dominated by filter-feeders, probably because of the elevated supply of particulate organic matter (Cook et al., 2006). In Croatia, near fish cages, the proliferation of sea urchins (Paracentrotus lividus and Arbacia lixula) in rocky reef habitats has been observed, resulting in overgrazing of seaweeds and the occurrence of barren grounds (Kušpilić et al., 2007).

Obviously, as pointed out by Ruiz et al. (2001), the impact resulting from fish farming is highly variable. It depends on water exchange, depth, aquaculture practices (fish feeding, fish yield, etc.) and on the vulnerability of the benthic ecosystem, e.g., the presence of $P$. oceanica meadows or rocky reef seaweed assemblages. Farms may not even have an impact on a given ecosystem; for example, no impact of fish farms on Carpodesmia amentacea (= Cystoseira amentacea; Ochrophyta) distribution along the French coast has been recorded (Thibaut et al., 2014).

\section{SEA URCHIN SEEDING}

The edible sea urchin Paracentrotus lividus is, together with the fish Sarpa salpa, the main native macro-herbivore in the Mediterranean Sea (Verlaque, 1987; Boudouresque and Verlaque, 2013). Other herbivorous fish, the native parrotfish Sparisoma cretense and the introduced (from the Red Sea) rabbitfishes Siganus luridus and S. rivulatus, are common in the eastern basin and are currently spreading toward the west, because of the warming of the sea surface water (Por, 1978; Astruch et al., 2016; Karachle et al., 2016). Paracentrotus lividus is sometimes erroneously considered as in decline, which would have "negative" consequences on the health status of ecosystems; this is due to over-harvesting (see e.g., Guidetti et al., 2004; Couvray, 2014; Couvray et al., 2015; Sartori et al., 2015), as its gonads (roe) are appreciated as a luxury seafood, especially in France, Spain, Italy, and Greece (Ballesteros and Garcia Rubies, 1987; Ledireac'h, 1987; Ledireac'h et al., 1987). However, at least in some Mediterranean areas, e.g., in Corsica, there is no sign of overexploitation, as highlighted by Duchaud et al. (2018). Although the actual baseline of the population density of $P$. lividus in the Mediterranean is unknown, there are reasons to think that its abundance, in the second half of the 20th century, could be, at least partly, a consequence of human impact (overfishing of its predatory fish, organic pollution) (Boudouresque and Verlaque, 2013); it is usually uncommon in No-Take Zones of Marine Protected Areas, i.e., zones where all types of fishing and harvesting (fish, custaceans and echinoderms), both amateur and commercial, are banned (Boudouresque et al., 1992), and proliferates in the vicinity of untreated domestic sewage outfalls (Harmelin et al., 1981; Boudouresque and Verlaque, 2013) and fish farms (Kušpilić et al., 2007). This man-induced proliferation of $P$. lividus has resulted in the extirpation of seaweed forests, e.g., Carpodesmia spp., Treptacantha spp. (formerly Cystoseira spp.), and Sargassum spp.; many of them are species endemic to the Mediterranean; they play a key role in Mediterranean coastal ecosystems (Thibaut et al., 2005, 2015; Blanfuné et al., 2016; Thibaut et al., 2016, 2017), and their replacement by barren grounds is a concerning issue (Fraschetti et al., 2011; Agnetta et al., 2015; Ling et al., 2015).

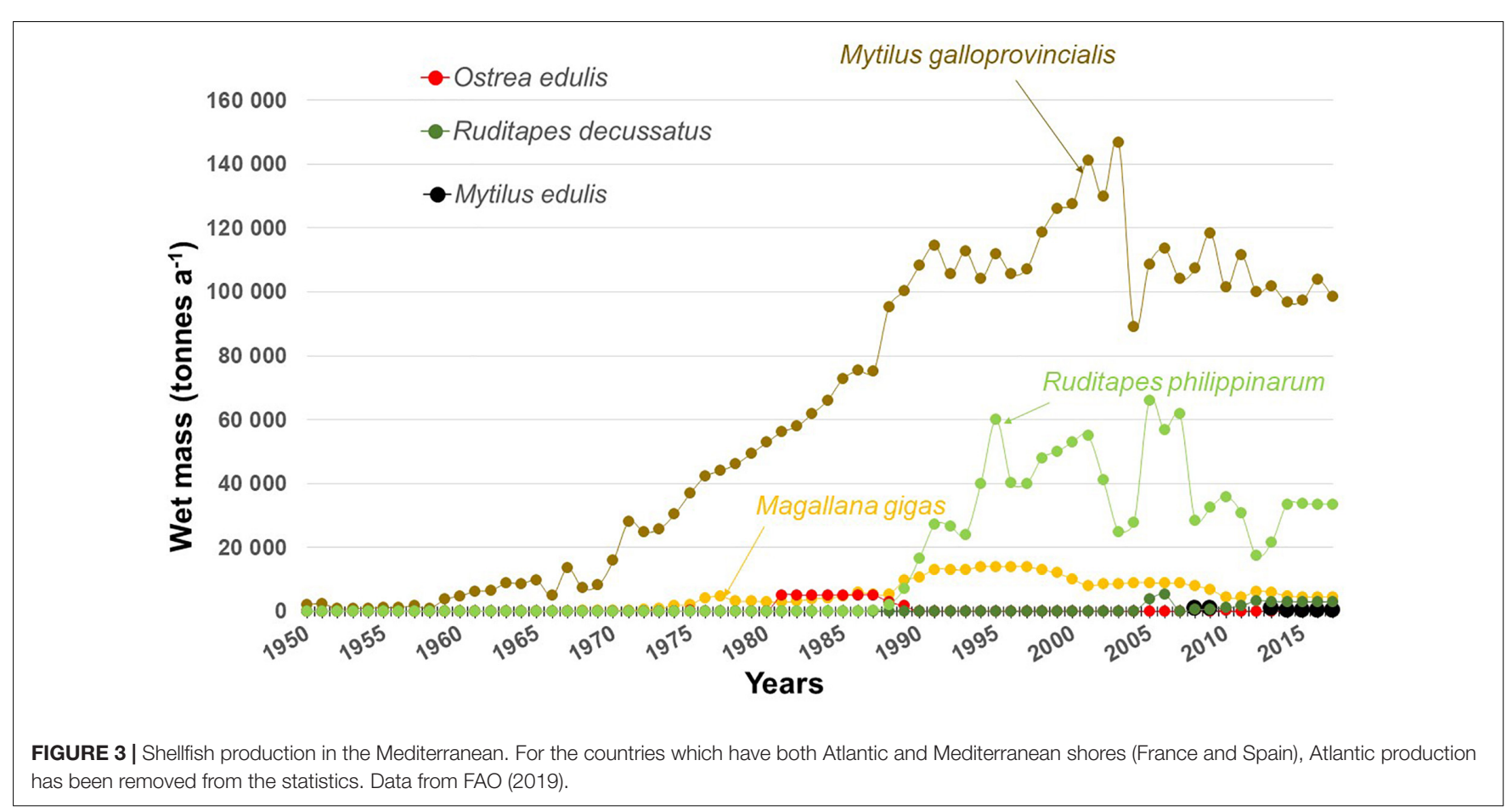


TABLE 1 | Seaweeds probably non-indigenous to the Mediterranean, of which the vector (or one of multiple vectors) is oyster aquaculture.

\begin{tabular}{|c|c|c|c|c|}
\hline Species & Origin & $\begin{array}{l}\text { First mediterranean } \\
\text { record }\end{array}$ & $\begin{array}{l}\text { Countries of current } \\
\text { occurrence }\end{array}$ & Habitat and status \\
\hline \multicolumn{5}{|l|}{ Rhodobionta (Archaeplastida) } \\
\hline Aglaothamnion halliae & E Atlantic & Venice (It), 2016 & It & Lagoons, Mid \\
\hline Agardhiella subulata & W Atlantic or NE Pacific & Thau (Fr), 1984 & Fr, It & Lagoons, Intro, C \\
\hline Ahnfeltiopsis flabelliformis & Japan & Thau (Fr), 1984 & $\mathrm{Fr}$ & Lagoons, Intro, C \\
\hline Antithamnion nipponicum & Japan & Thau (Fr), 1988 & Fr, It & Lagoons, Inv, C \\
\hline Chondria coerulescens & Atlantic & Thau (Fr), 1995 & $\begin{array}{l}\text { Al, Cy, Es, Fr, Gr, It, Lb, } \\
\text { Ly, Mo, Slo, Tna }\end{array}$ & $\begin{array}{l}\text { Lagoons, shallow reefs, } \\
\text { Intro }\end{array}$ \\
\hline Chondrus giganteus & Japan & Thau (Fr), 1994 & $\mathrm{Fr}$ & Lagoons, Intro \\
\hline Chrysymenia wrightii & Japan & Thau (Fr), 1978 & $\mathrm{Fr}$ & Lagoons, Intro \\
\hline Colaconema codicola & Japan ? & $\begin{array}{l}\text { French Catalonia, } \\
\text { before } 1952\end{array}$ & Al, Es, Fr, It, Mon, Tn, Tr & $\begin{array}{l}\text { Lagoons, shallow reefs, } \\
\text { Intro, CC }\end{array}$ \\
\hline Dasya sessilis & Japan & Thau (Fr), 1984 & $\mathrm{Fr}$ & Lagoons, Inv, CC \\
\hline Dasysiphonia japonica & Japan & Thau (Fr)n 1998 & Fr, It & Lagoons, Intro, C \\
\hline Gracilaria vermiculophylla & Pacific & Adriatic (It), 2008 & It & $\begin{array}{l}\text { Lagoons, shallow open } \\
\text { sea, Intro }\end{array}$ \\
\hline Grateloupia asiatica & Japan & Thau (Fr), 1984 & $\mathrm{Fr}$ & Lagoons, Intro, C \\
\hline Grateloupia lanceolata & Japan & Thau (Fr), 1982 & Fr, It (?) & Lagoons, Intro, CC \\
\hline Grateloupia minima & NE Atlantic & Thau (Fr), 1998 & Fr, It & Lagoons, Intro, C \\
\hline Grateloupia patens & Japan & Thau (Fr), 1994 & $\mathrm{Fr}$ & Lagoons, Cas, R \\
\hline Grateloupia subpectinata & Japan & Thau (Fr), 1990 & $\mathrm{Fr}$ & Lagoons, Intro, C \\
\hline Grateloupia turuturu & Japan & Thau (Fr), 1982 & Es?, Fr, Is, It & Lagoons, Intro, CC \\
\hline Grateloupia yinggehaiensis & China & & It & Lagoons, R \\
\hline Griffithsia corallinoides & NE Atlantic and Japan & Sicily (It), 1964 & Fr, Al (?), It, Tn, Tr & $\begin{array}{l}\text { Lagoons, shallow reefs, } \\
\text { Intro, CC }\end{array}$ \\
\hline Herposiphonia parca & Japan & Thau (Fr), 1997 & $\mathrm{Fr}$ & Lagoons, Intro, C \\
\hline Hypnea valentiae & Japan & Thau (Fr), 1996 & Fr, Gr, It, Lb, Mo & $\begin{array}{l}\text { Lagoons, shallow reefs, } \\
\text { C }\end{array}$ \\
\hline Laurencia okamurae & Japan & Thau (Fr), 1984 & $\mathrm{Fr}$ & Lagoons, Intro, C \\
\hline Lithophyllum yessoense & Japan & Thau (Fr), 1994 & $\mathrm{Fr}$ & Lagoons, Intro, C \\
\hline Lomentaria flaccida & Japan & Thau (Fr), 2002 & $\mathrm{Fr}$ & Lagoons, Cas \\
\hline Lomentaria hakodatensis & NE Pacific & Thau (Fr), 1978 & Fr, It & Lagoons, Intro, CC \\
\hline Melanothamnion japonicus & Japan & Venice (It) 2016 & It & Lagoons \\
\hline Nemalion vermiculare & N Pacific & Thau (Fr), 2005 & $\mathrm{Fr}$ & Lagoons, Intro, C \\
\hline Neosiphonia harveyi & Japan & Thau (Fr) 1958 & $\begin{array}{l}\text { Al, Eg, Es, Fr, Gr, It, Mo, } \\
\text { Sy }\end{array}$ & $\begin{array}{l}\text { Lagoons, shallow reefs, } \\
\text { CC }\end{array}$ \\
\hline Nitophyllum stellato-corticatum & Japan & Thau (Fr), 1984? & $\mathrm{Fr}$ & Lagoons, Intro, C \\
\hline Polysiphonia atlantica & Atlantic & $\begin{array}{l}\text { Berre lagoon (Fr), } \\
\text { 1969-1971 }\end{array}$ & $\begin{array}{l}\text { Al (?), Cy, Es, Fr, Gr, It, } \\
\text { Lb, Ly, Mo, Tn }\end{array}$ & $\begin{array}{l}\text { Lagoons, shallow reefs, } \\
\text { Intro, } R\end{array}$ \\
\hline Polysiphonia fucoides & Atlantic & $\begin{array}{l}\text { Prevost lagoon (Fr), } \\
1988\end{array}$ & $\begin{array}{l}\text { Al, Cy, Es, Fr, Gr, Hr, Is, } \\
\text { It, Mo, Slo, Tn, Tra }\end{array}$ & $\begin{array}{l}\text { Lagoons, shallow reefs, } \\
\text { Intro, } R\end{array}$ \\
\hline Polysiphonia morrowii & Japan or Korea & Thau (Fr), 1997 & Fr, It, Tr & Lagoons, Intro, C \\
\hline Pterosiphonia tanakae & Japan & Thau (Fr), 1993 & $\mathrm{Fr}$ & Lagoons, Intro, CC \\
\hline Pyropia yezoensis & Eastern Pacific & Thau (Fr), 1975 & $\mathrm{Fr}$ & $\begin{array}{l}\text { Midlittoral lagoons, } \\
\text { Intro, CC }\end{array}$ \\
\hline Rhodophysema georgii & Japan or NE Atlantic & Thau (Fr), 1978 & Fr, $\mathrm{Tr}$ & Lagoons, Intro, RR \\
\hline Solieria filiformis & N Atlantic & $\begin{array}{l}\text { Mar Piccolo di Taranto } \\
\text { (It), } 1922\end{array}$ & Fr, Is, It & Lagoons; Intro \\
\hline \multicolumn{5}{|l|}{ Chlorobionta (Archaeplastida) } \\
\hline Cladophora hutchisioides ${ }^{\mathrm{b}}$ & Japan or Australia & Thau (Fr), 2002 & $\mathrm{Fr}$ & Lagoons, Intro, C \\
\hline Codium fragile & Japan? & $\begin{array}{l}\text { Banyuls-sur-Mer (Fr), } \\
1946\end{array}$ & $\begin{array}{l}\text { Al, Es, Fr, Gr, Hr, It, Ly, } \\
\text { Mo, Slo, Tn, Tr }\end{array}$ & $\begin{array}{l}\text { Lagoons, shallow reefs, } \\
\text { Intro, CC }\end{array}$ \\
\hline Codium taylori & Atlantic or Pacific & Israel, 1955 & Eg, Is, Lb, Ly, Sy & Subtidal reefs, Intro \\
\hline Derbesia rhizophora & Japan? & Thau (Fr), 1984 & Fr & Lagoons, Intro, C \\
\hline Ulva australis (= U. pertusa) & Japan? & Thau (Fr), 1984 & Fr, It, Tr & Lagoons, Intro, CC \\
\hline
\end{tabular}


TABLE 1 | Continued

\begin{tabular}{|c|c|c|c|c|}
\hline Species & Origin & $\begin{array}{l}\text { First mediterranean } \\
\text { record }\end{array}$ & $\begin{array}{l}\text { Countries of current } \\
\text { occurrence }\end{array}$ & Habitat and status \\
\hline Ulva californica & N Pacific & Venice (It), 2011 & It & Lagoons, Cas or Intro? \\
\hline Ulva lactuca $(=U . \text { fasciata })^{\mathrm{a}, \mathrm{c}}$ & Japan & $\begin{array}{l}\text { Alexandria (Eg), } \\
\text { 1798-1801 }\end{array}$ & $\begin{array}{l}\text { Al, Eg, Es, Fr, Gr, Hr, Is, } \\
\text { It, Lb, Ly, Mo, Sy, Tn, Tr }\end{array}$ & $\begin{array}{l}\text { Lagoons, subtidal } \\
\text { reefs, Intro, C }\end{array}$ \\
\hline Ulvaria obscura & NE Atlantic or N Pacific & Thau (Fr), 1985 & Fr, It & Lagoons, Intro, CC \\
\hline Uronema marinum & Australia & $\begin{array}{l}\text { Venice and other } \mathrm{N} \\
\text { Adriatic lagoons }\end{array}$ & It & Laggons, Intro, C \\
\hline \multicolumn{5}{|l|}{ Ochrophyta (Stramenopiles) } \\
\hline Acrothrix gracilis & Japan & Thau (Fr), 1998 & $\mathrm{Fr}$ & Lagoons, Intro, R \\
\hline Ascophyllum nodosum & NE Atlantic & $\begin{array}{l}\text { Mar Piccolo di Taranto } \\
\text { (It), } 2012\end{array}$ & It & Lagoons, Cas \\
\hline Botrytella parva & Japan & Venice (It), 1996 & It, $\mathrm{Tr}$ & Lagoons, Cas \\
\hline Chorda filum? & N Atlantic & Greece, 1899 & $\mathrm{Fr}, \mathrm{Gr} ?, \mathrm{Tr}$ & Lagoons, Intro, C \\
\hline Cladosiphon zosterae & NE Atlantic & Venice (It), 1996 & $\mathrm{Fr}, \mathrm{It}, \mathrm{Tr}$ & Lagoons, Intro, R \\
\hline Colpomenia peregrina & NE Pacific & Thau (Fr), 1918 & Al, Es, Fr, Gr, It, Mo, Tr & $\begin{array}{l}\text { Lagoons, shallow reefs, } \\
\text { Intro, CC }\end{array}$ \\
\hline Cutleria multifida $^{\mathrm{d}}$ & Japan & Cannes (2008) & $\mathrm{Fr}, \mathrm{It}, \mathrm{Gr}$ & Subtidal reefs, Intro, C \\
\hline Desmarestia viridis & NE Atlantic or N Pacific & Thau (Fr), 1978 & Fr, It & Lagoons, Intro, CC \\
\hline Ectocarpus siliculosus var. hiemalis & N Atlantic & Turkey, 1986 & It, $\mathrm{Tr}$ & Shallow reefs, Cas \\
\hline Halothrix lumbricalis & N Atlantic or N Pacific & Acicastello (It), 1978 & $\mathrm{Fr}, \mathrm{It}, \mathrm{Tr}$ & $\begin{array}{l}\text { Lagoons, shallow reefs, } \\
\text { Intro, C }\end{array}$ \\
\hline Leathesia marina (= L. difformis) & N Atlantic or N Pacific & Thau (Fr), 1905? & Fr, It & Lagoons, Intro, C \\
\hline Microspongium stilophorae ${ }^{\mathrm{a}}$ & N Atlantic & Thau (Fr), 2005 & $\mathrm{Fr}$ & Lagoons \\
\hline Punctaria tenuissima & Japan & $\begin{array}{l}\text { Jabuka Island }(\mathrm{Hr}) \text {, } \\
\text { 1947-1956 }\end{array}$ & Fr, Hr, It, Tr & $\begin{array}{l}\text { Lagoons, shallow reefs, } \\
\text { Intro, C }\end{array}$ \\
\hline Pylaiella littoralis ${ }^{\mathrm{e}}$ & NE Atlantic or N Pacific & Venice (It), 1962 & $\begin{array}{l}\text { Es, Fr, Gr, Hr, It, Slo, } \\
\text { Tn, Tr }\end{array}$ & Lagoons, Intro, CC \\
\hline Rugulopteryx okamurae & Japan & Thau (Fr), 2002 & Es, Fr, Gib, Mo & $\begin{array}{l}\text { Lagoons, shallow reefs, } \\
\text { Inv, CC }\end{array}$ \\
\hline Saccharina japonica & Japan & Thau (Fr), 1976 & $\mathrm{Fr}$ & Lagoons, Cas \\
\hline Sargassum muticum & Japan & Thau (Fr), 1980 & Es, Fr, It & Lagoons, Inv, CC \\
\hline Scytosiphon dotyi & NE Pacific & Trieste (It), 1960-1977 & Es, Fr, It, Tr & Lagoons, Intro, R \\
\hline Sphaerotrichia firma & Japan & Aegean Sea (Tr), 1970 & $\mathrm{Fr}, \mathrm{Tr}$ & $\begin{array}{l}\text { Lagoons, shallow reefs, } \\
\text { Intro, C }\end{array}$ \\
\hline Undaria pinnatifida & Japan & Thau (Fr), 1971 & Fr, It & Lagoons, Intro, CC \\
\hline
\end{tabular}

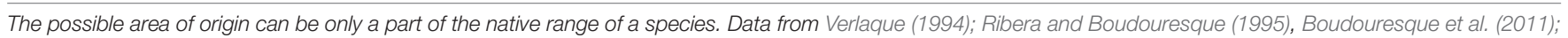

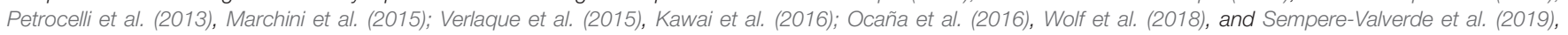

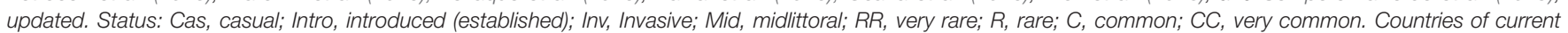

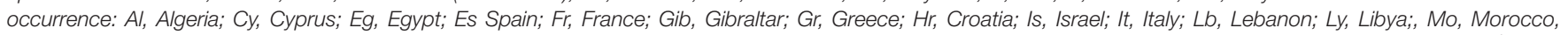

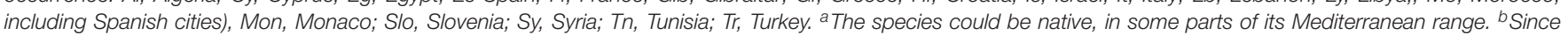

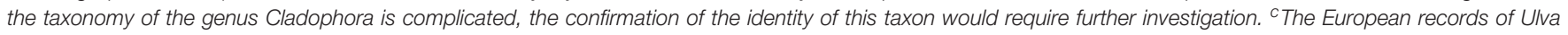

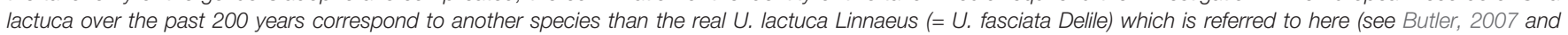

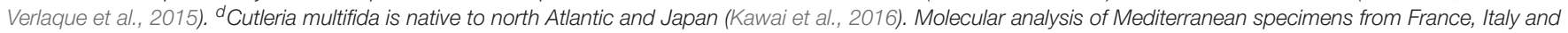

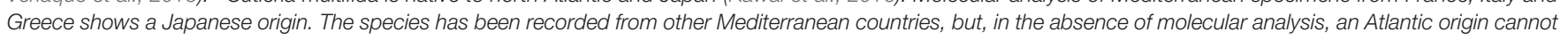
be excluded. e Pylaiella littoralis is regarded as introduced only in the northern lagoons of the Mediterranean Nerlaque et al., 2015).

As expected, harvesting results in a decline in density, mean size and percentage of individuals of the largest size classes (Bertocci et al., 2014, 2018). However, the lack of large individuals (the commercial size class) in a highly harvested area of Sardinia does not seem to be alarming for the self-supporting capacity of the population, as the reproductive potential is mainly due to undersized individuals: the amount of released gametes is similar in harvested and non-harvested areas (Loi et al., 2017).

The attempts to restore sea urchin abundance, via seeding of juveniles from hatcheries, whether or not effective (see below), and the possible disproportionate financial cost of such operations, cannot be referred to as "ecosystem restoration," but rather as "extensive aquaculture." It is likely that they contribute to further accentuating the artificialization of the environment, for the possible benefit of humans needs, and not to the restoration of its naturalness. In order to mitigate the supposed decline of $P$. lividus populations, and to respond to the growing market demand, land-based and offshore aquaculture, and the reseeding of depleted sites, with juveniles reared in hatcheries, has been considered (e.g., Couvray, 2014; Couvray et al., 2015; Sartori et al., 2015, 2016; Shpigel et al., 2018; Volpe et al., 2018; Zupo et al., 2019). For example, 250,000 


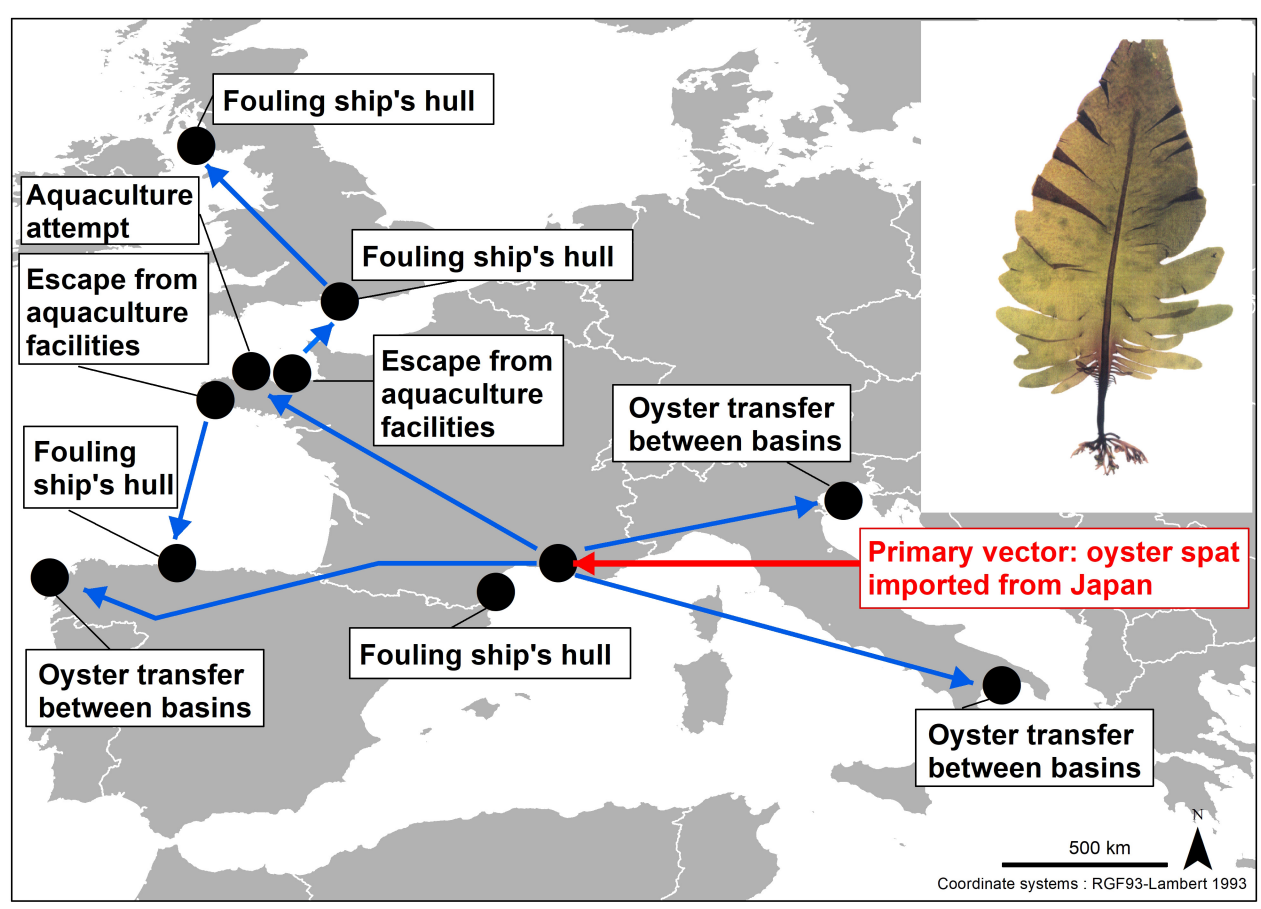

FIGURE 4 | Primary (red arrow) and secondary (blue arrows) vectors of spread of Undaria pinnatifida ("brown alga," Stramenopiles) in the Mediterranean and western Europe. Only some of the sites where U. pinnatifida occurs, along the western coasts of Europe, have been represented.

hatchery produced juveniles were released in eastern Provence (France); a year after release, they represented 3 and 12\% of total recaptured urchins at two experimental sites (Couvray et al., 2015). In Asturias (Atlantic Spain), all small individuals (10$30 \mathrm{~mm}$ ) released on substrates with burrows did not survive the first few weeks, and only those that were released on substrates with large individuals successfully settled (12\%) (de la Uz et al., 2018). This preference of juveniles for habitats with abundant adults could explain the relative failure of some reseeding operations, which for intuitively logical reasons, are carried out in depopulated areas rather than in already densely populated areas. Hatchery rearing of $P$. lividus can cause bottleneck effects (i.e., a substantial reduction in genetic diversity and differentiation from wild populations), as hatchery-reared populations are less diverse than wild populations (Segovia-Viadero et al., 2016). This highlights the need to consider the genetic risks of releasing hatchery-reared juveniles into the wild in the framework of stock enhancement and sea ranching programs (Segovia-Viadero et al., 2016). However, according to Couvray et al. (2015), in eastern Provence, genetic diversity seems not to be affected by introducing juveniles from the hatchery.

\section{SHELLFISH AQUACULTURE}

Mediterranean shellfish aquaculture has grown steadily over the years, although with a lower rate of increase than that of fish farming, and a relative plateau or decline since the 1990s: $17 \mathrm{kt}$ in 1970, $56 \mathrm{kt}$ in 1980, $141 \mathrm{kt}$ in 1990, $190 \mathrm{kt}$ in 2000,

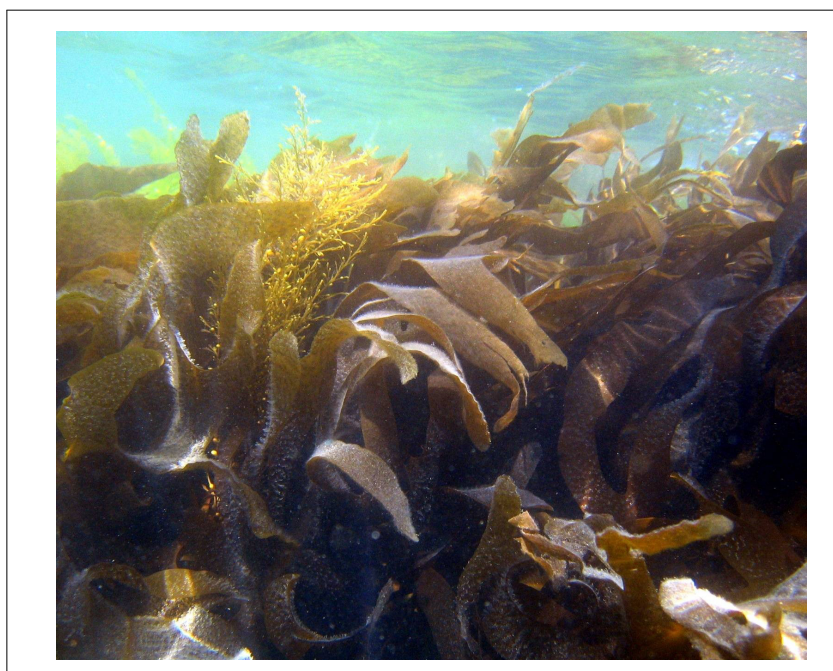

FIGURE 5 | Seascape on a shallow rocky substrate near Meze, Thau Lagoon (France). The brown blades: Undaria pinnatifida. The yellowish filaments (above, to the left): Sargassum muticum. The sketch below (Figure 6) shows the rest of the macrophyte stand. Photo: courtesy of Sandrine Ruitton.

and $137 \mathrm{kt}$ in 2010; fish production is now higher than that of shellfish (Figure 3; Basurco and Lovatelli, 2003; FAO, 2019). Three species of bivalves constitute the bulk of the shellfish aquaculture in the Mediterranean Sea (Basurco and Lovatelli, 2003): the mussel Mytilus galloprovincialis, which is native to the Mediterranean (mainly farmed in Italy, Grece and France), the 


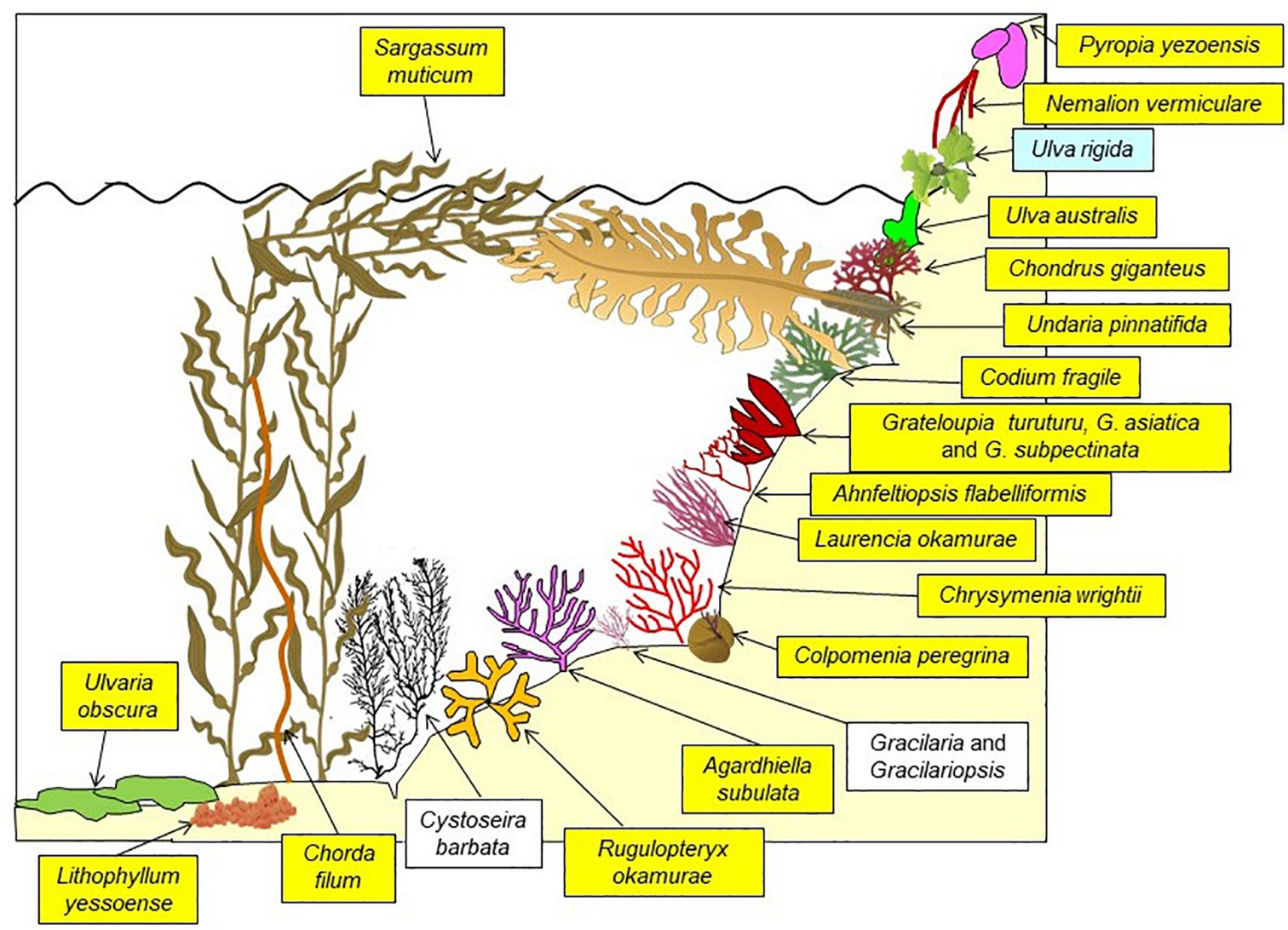

FIGURE 6 | A sketch of the dominant macrophytes on shallow (down to $1 \mathrm{~m}$ depth) rocky substrates of the Thau Lagoon in spring. Names on a yellow background: introduced species; blue background: probably cryptogenic introduction; white background: native species. From Boudouresque et al. (2011), modified and updated.

Pacific oyster Magallana gigas (= Crassostrea gigas) (mainly in France), native to the Pacific coast of Asia (Salvi and Mariottini, 2017), and the Manila clam Ruditapes philippinarum (mainly in Italy), native to the coasts of the Indian and Pacific Oceans, from Pakistan to Japan and the Kuril Islands (Goulletquer, 2005). Three other species are bred, but the quantities produced are very limited: the Atlantic mussel Mytilus edulis, the flat oyster Ostrea edulis and the grooved carpet shell Ruditapes decussatus (Figure 3) Magallana gigas escaped from sea farms and is now introduced (naturalized) in the Mediterranean; in contrast with the European Atlantic coasts, it is not invasive there (Zenetos et al., 2005; Wrange et al., 2010; see Boudouresque and Verlaque, 2002, 2012, for invasion terminology). Ruditapes philippinarum escaped from sea farms and was also deliberately introduced, as in the Venice and Berre lagoons; it is locally invasive and its abundance is considered welcome by local fishermen (Mazzola, 1992; Occhipinti Ambroggi, 2001; Pranovi et al., 2003, 2006).

Shellfish aquaculture can affect macrophytes of Mediterranean ecosystems via four processes: a major source of non-indigenous seaweeds, a flow of propagules that can flood macrophyte forests, a vector of diseases of metazoans of which the extirpation changes the functioning of recipient ecosystems, and a change in the functioning of the recipient ecosystem, including a direct effect of the shower of fecal pellets on bottom macrophytes.

\section{A Major Source of Non-indigenous Seaweeds}

Oyster culture has been a mass vector for the introduction of macroalgae in the Mediterranean, as in many regions of the earth: "The greatest agency of all that spreads marine animals [and plants] to new quarters of the world must be the business of oyster culture" (Elton, 1958; Verlaque et al., 2007b; Grigorakis and Rigos, 2011). As many as 65 Non-Indigenous Species (NIS) have been recorded in the Mediterranean (Table 1) of which the arrival is linked, directly or indirectly, to shellfish aquaculture, that of the Pacific oyster Magallana gigas for the most part, but also the Manila clam Ruditapes philippinarum in the case of Aglaothamnion halliae, Gracilaria vermiculophylla, and Uronema marinum (Sfriso et al., 2014; Verlaque et al., 2015; Wolf et al., 2018). Between 1968 and 1983, large amounts of oyster spat (up to $200 \mathrm{t} \mathrm{a}^{-1}$ ) were directly imported from Japan (the Bay of Mangoku-Ura, near Sendai) to Thau Lagoon (Occitania, France); in fact, these imports continued well after their official ban in 1983 (Verlaque, 2001). Theoretically, the spat was to be immerged 
TABLE 2 | A grid that shows the eligibility of fish farming sites, according to the distance from the nearest Posidonia oceanica meadow, the depth, the water movement (openness of the site) and the size of the farm (in wet mass - metric tons - of fish produced per year). Greater distances would of course be welcome.

\begin{tabular}{|c|c|c|c|c|c|c|}
\hline Depth & Openness & $<100 \mathrm{~m}$ & $100-200 \mathrm{~m}$ & 200-300 m & $300-400 \mathrm{~m}$ & $>400 \mathrm{~m}$ \\
\hline \multirow[t]{2}{*}{$<5 \mathrm{~m}$} & Open & & & & $<100 t$ & $<500 t$ \\
\hline & Not open & & & & & $<100 t$ \\
\hline \multirow[t]{2}{*}{ 5-10 m } & Open & & & $<100 t$ & $<500 t$ & $<1000 t$ \\
\hline & Not open & & & & $<100 t$ & $<500$ \\
\hline \multirow[t]{2}{*}{ 10-20 } & Open & & $<100 t$ & $<500 t$ & $<1000 t$ & $<2000 t$ \\
\hline & Not open & & & $<100 t$ & $<500 \mathrm{t}$ & $<1000 t$ \\
\hline \multirow{2}{*}{ 20-40 m } & Open & & & $<100 t$ & $<500 t$ & $<1000 t$ \\
\hline & Not open & & & & $<100 \mathrm{t}$ & $<500 \mathrm{t}$ \\
\hline \multirow[t]{2}{*}{$>40 \mathrm{~m}$} & Open & & $<500 t$ & $<1000 t$ & $<2000 t$ & $<5000 t$ \\
\hline & Not open & & $<100 t$ & $<500 t$ & $<1000 t$ & $<2000 t$ \\
\hline
\end{tabular}

In gray, the combination of factors resulting in exclusion. Open sites or not open sites: located outside a bay or within an embayment. After Boudouresque et al. (2012).

for $4 \mathrm{~h}$ in fresh water in order to kill exotic epibionts, before immersion in the lagoon (Piquion, 1985), however, this operation was under the sole responsibility of the farmers, who of course did not do it; in addition, freshwater treatment is ineffective in eliminating macroalgae (Verlaque et al., 2007a). Shellfish aquaculture is the main vector of non-indigenous macrophytes in the Mediterranean (42\%), ahead of the Suez Canal, fouling, and aquariums. Unsurprisingly, the main region of origin is the North-East Pacific (mainly Japan and Korea) (83\% of the taxa) and the main primary recipient area in the Mediterranean is Thau Lagoon (66\%).

Most of the known attempts of NIS to become introduced have been successful (89\%; Table 1). The cases of failure (casual species: recorded once, or for a few years, then apparently extinct) are those of Grateloupia patens, Lomentaria flaccida, Ulva californica, Botrytella parva, Ascophyllum nodosum, Ectocarpus siliculosus var. hiemalis, and Saccharina japonica.

Primary vectors (from the region of origin to the recipient area) can be identical to secondary vectors (from a recipient area acting as a hub to a new recipient area), or different. Undaria pinnatifida arrived at Thau Lagoon via a primary vector, i.e., directly from the Bay of Mangoku-Ura (Japan), with imported oyster spat (Figure 3; Boudouresque et al., 1985). Subsequently, Thau Lagoon acted as a hub for the dispersal of the species to new areas, via secondary vectors. In some cases, the secondary vector was similar to the primary one, namely the transfer of adult oysters from one aquaculture basin to another (Occhipinti Ambrogi, 2000); adult transfers are common in the oyster business, oysters beginning to grow in one basin (e.g., Thau) and then being transferred to another (e.g., Marennes-Oleron, Atlantic coast of France) for the final affinage (refining process). Secondary vectors can also be different: fouling on ship hulls or escape from a seaweed farm (Figure 4; Boudouresque et al., 1985; Brault and Briand, 1987; Floc'h et al., 1996; Cecere et al., 2000). Solieria filiformis probably arrived in the Mediterranean via shipping (fouling on ships' hulls: primary vector), but was subsequently spread by oyster transfers (secondary vector) (Verlaque et al., 2015).

The impact of invasive species on native species and/or native ecosystems is well known and therefore of major concern: species extinction, e.g., on islands, local extinctions, functional extinctions and disruption of the ecosystem functioning (e.g., Boudouresque, 1997; Schmitz and Simberloff, 1997; Balmford and Bond, 2005; Boudouresque et al., 2005; Clavero and GarciaBerthou, 2005). However, most studies consider the impact of a given invasive species on native species, rather than the collective impact of a pack of invasive species (Boudouresque, 1999a). In fact, a large number of introduced species can coexist in the same ecosystem, as occurs in e.g., coastal lagoons, along the Tuscany coast (Italy) and in the eastern Mediterranean basin (Piazzi and Cinelli, 2003; Piazzi and Balata, 2009; Boudouresque et al., 2011). Introduced species can of course compete with each other (Piazzi and Ceccherelli, 2002). Thau Lagoon illustrates the disruption of the ecosystems and seascapes by a host of introduced macroalgae, which may outnumber the native species, and represent the bulk of the biomass of primary producers in some habitats. Boudouresque et al. (2011) have even compared Thau Lagoon with a "Japanese botanical garden": overall, 121 putatively native species and 58 introduced species, most of them of Japanese origin, currently occur there (Figures 5, 6). Putatively native species include cryptogenic species (sensu Carlton, 1996), i.e., species which are today more or less cosmopolitan, but were probably introduced in most parts of their current range, before the 18th century and the beginning of the Linnean Era; Ulva rigida (Table 2 and Figure 6) is probably a cryptogenic species. On rocky shallow substrates, the seascape is dominated by introduced species, which can account for $97-99 \%$ and $48-$ $95 \%$ of the biomass in spring and autumn, respectively (Figures 5 , 6; Boudouresque et al., 2011). Many introduced macroalgae are also present, although in lesser numbers, in the Lagoon of Venice (28 species) (Occhipinti Ambrogi, 2000; Sfriso et al., 2012, 2014; Marchini et al., 2015; Sfriso et al., 2020) and in the Mar Piccolo di Taranto lagoon (13 species) (Petrocelli et al., 2019).

\section{A Flow of Propagules That Can Flood Macrophyte Forests}

The canopy-forming long-lived Carpodesmia mediterranea (Cystoseira mediterranea; Ochrophyta, Stramenopiles), which forms a dense belt on rocky reefs, at the upper part of the infralittoral zone (sensu Pérès and Picard, 1964), from the mean sea level down to $1 \mathrm{~m}$ depth, has experienced marked fluctuation of its abundance since the 1970s in French Catalonia (Gros, 1978; Blanfuné et al., 2019); the most realistic explanation for the episodes of sharp decline of $C$. mediterranea seems to be the invasion of the habitat by dense stands of the mussel Mytilus galloprovincialis. Mussels could reduce the survival rate of $C$. mediterranea recruits that settle on its shell because of the vulnerability of this substrate (prone to be pulled out by waves) and the low longevity of the mussels. In addition, there is a light deficit for the recruits of $C$. mediterranea that grow directly on the rocky substrate. Extreme storms are not uncommon in French Catalonia (Figure 7; Thibaut et al., 2005; Blanfuné et al., 2019; 


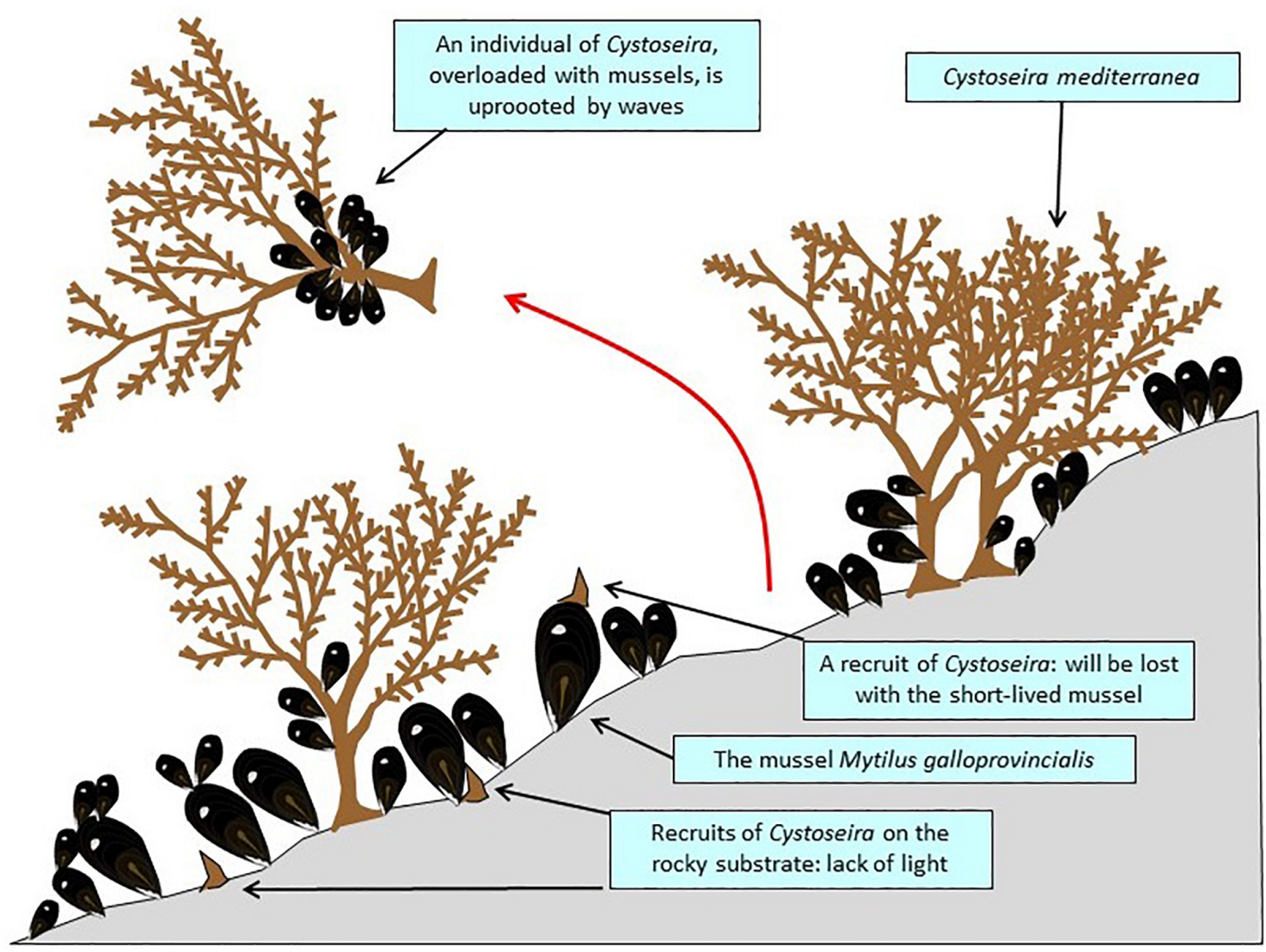

FIGURE 7| A stand of Carpodesmia mediterranea (= Cystoseira mediterranea), in French Catalonia, severely disrupted by mussels of which the recruits probably come from offshore mussel farms.

see Navarro et al., 2011, for Spanish Catalonia). The flow of mussel larvae could be due to the development of offshore mussel farms, off Sète, $\sim 100 \mathrm{~km}$ upstream, transported by the Northern Mediterranean Current toward Catalonia (Blanfuné et al., 2019). A similar negative impact of mussel proliferation on seaweeds has already been reported, e.g., in Sweden (Lundälv et al., 1986).

\section{A Vector of Diseases of Metazoans of Which the Extirpation Changes the Functioning of Recipient Ecosystems}

The transfer of farmed species from one region to another has not only been a vector for accompanying epibionts ("hitch-hikers"), but also for microbial pathogens and for metazoan parasites (Grigorakis and Rigos, 2011; Weitzman et al., 2019). Usually, it is not in the interests of a pathogen or a parasite to kill its host: if the host dies, they will die too. As a result, in the native range, coevolution has often shaped reciprocal adaptation: an equilibrium between a moderate parasite virulence and a moderate host response (Combes, 1995, 2001). However, especially in marine environment, some pathogens have interest to kill their host to maximize their dissemination using hydrodynamic connectivity (e.g., Fuhrman, 1999; van Kan, 2006; Avrani et al., 2012). In the absence of quarantine, farmed non-indigenous species can transfer their pathogens and parasites to native species (host shift). If their virulence is too high, they extirpate native new hosts. Movements of oysters from California to Maine, Washington and France brought the haplosporidian (kingdom Rhizaria) Bonamia ostreae, which caused the severe decline of the flat oyster Ostrea edulis (Barber, 1997; Ruesink et al., 2005). The actual origin of a number of parasites and viral diseases which affect marine species is unclear, although some of them could be of Asian origin (e.g., Comps and Duthoit, 1976; Comps et al., 1976; Comps, 1983; Ruesink et al., 2005; Miossec et al., 2009).

In the Mediterranean, the fan mussel Pinna nobilis, the largest Mediterranean mollusk (over $1 \mathrm{~m}$ tall), is a key species in the Posidonia oceanica seagrass ecosystem (Personnic et al., 2014). This long-lived species (over 40 years), endemic to the Mediterranean, is a filter-feeder (Butler et al., 1993; Trigos et al., 2014; Rouanet et al., 2015). A wasting disease (90\% to near $100 \%$ mortality) occurred in Spain in 2016 (Darriba, 2017; Vázquez-Luis et al., 2017). Subsequently, this mortality spread to the whole of the Mediterranean (GonzálezWangüemert et al., 2018; Pergent, 2018; Bianchi et al., 2019; Cabanellas-Reboredo et al., 2019). Mortality is caused by a unicellular parasite, Haplosporidium pinnae, a species previously undescribed (Catanese et al., 2018). According to Darriba (2017) and Catanese et al. (2018), H. pinnae could be either an old 
symbiont that has changed its relation with the host, due to the environmental changes, or a recently introduced species. The latter hypothesis is by far the most probable: the new parasite presents many of the features that characterize an introduced species (see Ribera and Boudouresque, 1995; Boudouresque, 1999a), e.g., the weak genetic diversity and the pattern of expansion. Many haplosporidans are parasites of bivalves in the north-western Pacific; some of them were introduced to Europe via shellfish transfers, with dire consequences (Sindermann, 1992; Cabanellas-Reboredo et al., 2019). The possible primary vector species of $H$. pinnae (Magalana gigas? Ruditapes philippinarum?) is still unidentified. Currents and ballast waters seem to have been involved in its spread within the Mediterranean (Cabanellas-Reboredo et al., 2019); in addition, a putative reservoir species (Mytilus galloprovincialis?) could account for long-distance dispersal.

\section{A Change in the Functioning of the Recipient Ecosystem}

Shellfish aquaculture can profoundly change the functioning of the ecosystems of the recipient lagoon or embayment by (i) removing Particulate Organic Matter (POM; including phytoplankton), via the activity of filter-feeder mollusks, (ii) removing nutrients via the export of farmed shellfish to markets, outside the aquaculture area, and (iii) via the shower of fecal pellets on the bottom compartment (with or without macrophytes), with mineralization which induces anoxy of the sediment, anoxy which can spread to the water column under low wind conditions (Deslous-Paoli et al., 1993; Plus et al., 2003; Gaertner-Mazouni and De Wit, 2012; Boudouresque, 2013; Weitzman et al., 2019).

In Thau Lagoon (Occitania, France), benthic macrophytes are well developed below shellfish facilities: Zostera marina (seagrass), Chaetomorpha linum (Chlorobionta), Gracilaria spp., Halopitys incurvus, and Rytiphloea tinctoria (Rhodobionta) (Plus et al., 2003). However, the baseline, before the development of shellfish aquaculture, is poorly known. According to De Casabianca et al. (2003), eutrophication, including the effects of shellfish farming, drives the regression of Zostera meadows and the expansion of Gracilaria and other seaweed stands. In another lagoon, Salses-Leucate (Occitania, France), the isotopic ratio of macrobenthos (including macrophytes) was not modified underneath the oyster facilities (Carlier et al., 2009).

\section{DICUSSION AND CONCLUSION}

Global marine captures by fisheries are declining, although this trend is greatly underestimated as small-scale fishery, recreational fishery, discards and of course Illegal, Unreported and Unregulated (IUU) fishery are poorly or not at all taken into account (Zeller et al., 2006; Kaiser and Hiddink, 2007; Pauly et al., 2014; Piroddi et al., 2015; Pauly and Zeller, 2016; but see Hilborn et al., 2020 for an alternative view). This trend is of course dependent upon the nature and extent of fisheries management systems (Hilborn et al., 2020). In the Mediterranean and Black Sea, the production from fisheries declined from about
1.4-1.2 $\mathrm{t} \mathrm{a}^{-1}$, from 1993 to 2013, because most fisheries stocks are overfished (Massa et al., 2017). In this context, aquaculture is an important option to feed a growing world population, which is estimated to reach 9 billion people by 2050 (Massa et al., 2017). It is often associated with the concepts of blue growth and blue economy, aiming at providing food and jobs and at the same time limiting the degradation of oceans and revitalizing ecosystems (Le Gouvello and Simard, 2017; Barbesgaard, 2018). This optimistic view of aquaculture should be seen in a more nuanced way by taking into account not only the benefits, but also the costs for natural habitats.

Fish farming is responsible for organic matter and nutrient loads that can be compared to those of small untreated sewage outfalls. At a time when, at least for the EU countries on the northern shore of the Mediterranean, the vast majority of terrestrial wastewater now passes through a sewage treatment plant (Kalavrouziotis et al., 2015), the rapid, strong increase in fish farming, and the resulting untreated loads of organic matter and nutrients, represents a paradox. A number of authors have developed rather optimistic views concerning nutrients, organic matter and trace elements which are released by fish farms and enter the recipient ecosystems. They consider that they are spatially limited, within the range of tolerable levels for the marine ecosystem and that an oligotrophic sea such as the Mediterranean is able to assimilate these loads (Basaran et al., 2010; Puhr and Pikelj, 2012; De Biasi et al., 2016). According to Puhr and Pikelj (2012), when carefully planned, fish farms do not necessarily degrade the health status of $P$. oceanica meadow, but in fact facilitate a transition to an alternative stable state that is "characterized by a delicate balance between organic input from fish farms and the capacity of the system to process it"; the difference between a degraded meadow and this "alternative stable state," as Puhr and Pikelj (2012) named it, is however unclear. Whatever the surface area of dead $P$. oceanica meadows resulting from fish farming, its is worth highlighting that seagrass dead mattes constitutes a kind of time bomb: the huge amounts of carbon which have been sequestrated within it over millennia can be mineralized into carbon dioxide and returned to the environment, contributing to global warming (Pergent et al., 2012, 2014).

Some authors have rightly pointed out that fish farms cause the increase, by a factor of up to 4, of the overall fish abundance and species diversity, at a spatial scale larger than the immediate vicinity of the fish cages, which constitutes a positive effect on local fisheries (e.g., Machias et al., 2004, 2005). However, it would be naïve, on the basis of a partial and erroneous view of the biodiversity concept, to extend this positive effect to the ecosystem and the environment (see Boudouresque, 2014, for the biodiversity concept). A partial recovery of the annelid fauna of a soft bottom ecosystem, near Murcia (Spain), one year after the cessation of the activities of a fish farm, gives grounds for optimism (AguadoGiménez et al., 2012), although the annelid assemblage is just a compartment of an ecosystem which also encompasses teleosts, echinoderms, mollusks, etc., compartments which are not addressed by the authors. It has been suggested that multitrophic aquaculture, i.e., the simultaneous farming of low trophic 
level organisms, such as bivalves and sea urchins, together with fish, would reduce fish waste impact, while enhancing total productivity (Troell et al., 2003; Israel et al., 2019). However, this optimistic hypothesis has been contradicted by Navarrete-Mier et al. (2011).

With the exception of Egypt, where fish farming is based on the semi-extensive production of mullet, which are omnivorous and opportunistic, most of the farmed fish species are carnivorous (Basurco and Lovatelli, 2003). In aquaculture facilities, they are fed both pelleted and mainly extruded feeds rich in protein (up to $600 \mathrm{~g} \mathrm{~kg}^{-1}$ ) and lipids (up to $260 \mathrm{~g}$ $\mathrm{kg}^{-1}$ ) (Kousoulaki et al., 2015). Most farmed fish diets include fishmeal and fish oil; they come from $\sim 14 \mathrm{Mt}$ whole fish and 5 Mt by-products of seafood processing, which produces 45 Mt fishmeal and $\sim 1$ Mt fish oil. Most of the fishmeal is now used to feed farmed fish (IFFO, 2019). According to Le Gouvello and Simard (2017) and IFFO (2019), the concern that expanding aquaculture would use more and more fishmeal and fish oil, and so would contribute either to fish depletion in the seas, or to the removal of a fish resource for populations of southern countries, is misplaced: the percentage of fishmeal in used fish diet is on the decline. In contrast, other authors accuse farming of carnivorous fish of being "the aquatic equivalent of robbing Peter to pay Paul": it transforms small pelagic and other fishes perfectly fit for human consumption into animal feeds the nutritive value of which is lost to humans (Goldburg and Naylor, 2005; Pauly et al., 2005; Jacquet and Pauly, 2008; Grigorakis and Rigos, 2011). It is worth noting that the pilot trial of offshore aquaculture of the sea urchin Paracentrotus lividus, on the Italian coast, was based upon anchovy and krill flour (Volpe et al., 2018), although this sea urchin is actually a herbivore (Boudouresque and Verlaque, 2013, 2020).

The recovery times of Posidonia oceanica meadows is in the order of at least decades and may be more than a century, so that losses can be considered to be irreversible at human time scales (Molinier and Picard, 1952; Boudouresque and Meinesz, 1982; Holmer et al., 2003; Boudouresque et al., 2009, 2012). According to Holon et al. (2018), the tipping point (shift from a healthy $P$. oceanica meadow to a significantly degraded meadow) is situated, on average, $320 \mathrm{~m}$ from a fish farm. A safety distance of $400 \mathrm{~m}$ has been suggested between fish farms and the nearest $P$. oceanica meadow (Holmer et al., 2008). Boudouresque et al. (2012) have proposed the following recommendations: (i) No fish farm facilities should be directly established over a $P$. oceanica meadow. In Spain, no fish farm facilities have been directly established over $P$. oceanica meadows, and the existing ones have been moved offshore; however, this is not the case in most other Mediterranean countries. (ii) If there is a meadow nearby, minimum distances from the cages should be respected. They depend upon the depth, the openness of the site (embayment or well-flushed open sea) and the size of the farm (Table 2); deep meadows are more sensitive to turbidity and overshadowing, so that farms established above deep bottoms should respect an increased safety distance from the nearest meadow. According to recent literature, these safety distances seem to be under-estimated, as nutrients release by fish farms may reach several kilometers of distance (e.g., Ruiz et al., 2010). (iii)
An installation of fish farm facilities on a $45-50 \mathrm{~m}$ deep seabed should be given priority, whenever possible. (iv) Permission to set up a fish farm should be reviewed every 4 years for possible extension, on the basis of a demonstration that the $P$. oceanica meadows located nearby have not regressed. In addition, permanent monitoring plots should be established and revisited annually to assess the health of the meadow (Holmer et al., 2008). Physiological parameters of $P$. oceanica leaves and rhizomes (e.g., total nitrogen content, free amino acid concentration and composition, stable nitrogen isotope ratio) are useful indicators of marine environmental degradation (Pérez et al., 2008). For monitoring methods for P. oceanica meadows, see Boudouresque et al. (2007, 2012), Personnic et al. (2014), and Boudouresque et al. (2015b). Similar recommendations could apply to coralligenous and coastal detritic ecosystems, although no minimum distance has been proposed for them. Whatever the ecosystem concerned, monitoring programs are of paramount importance (e.g., Borja et al., 2009; De Biasi et al., 2016).

Overall, in the Mediterranean, fish farming can have very negative impact; the impact has mostly been studied on Posidonia oceanica seagrass beds, but obviously it also concerns coralligenous and coastal detritic ecosystems. It can be direct (shading, fecal pellets) and indirect (overgrazing). Shellfish aquaculture is the major source (ahead of the Suez Canal and fouling on ship hulls) of the introduction of exotic macrophyte species which deeply disrupt lagoon landscapes and ecosystems. As far as the sea urchin seeding is concerned, fortunately, it is not very effective, which avoids aggravation of the overgrazing of marine forests.

The above conclusions do not call into question marine aquaculture, but underline the importance of taking into account its possible negative effects, in order to avoid them. This requires taking them into account at the very beginning of the project design process. In addition, some knowledge gaps for future research avenue on the thematic deserve to be more developed, e.g., (i) surveillance networks, not only of species, groups of species and functional compartments, but also on the whole ecosystem functioning; (ii) active restoration, after the cessation of aquaculture activities, versus natural restoration (in many cases, nature do things better than humans); (iii) assessing in a less empirical way, using maps of ecosystem distribution and local scale models of currents, the safety distance between aquaculture facilities and high heritage value ecosystems.

\section{AUTHOR CONTRIBUTIONS}

All authors equally contributed to the writing of the manuscript.

\section{ACKNOWLEDGMENTS}

We are indebted to Michael Paul, a native English speaker, for proofreading the text, to four reviewers for the valuable suggestions, and to the editors of this Research topic, especially to Margarida Casadevall and Jonathan Richir. 


\section{REFERENCES}

Abu-Zeid, M. A., and El-Shibini, F. Z. (1997). Egypt's high aswan dam. Wat. Res. Dev. 13, 209-217.

Agnetta, D., Badalamenti, F., Ceccherelli, G., Di Trapani, F., Bonaviri, C., and Gianguzza, P. (2015). Role of two co-occurring Mediterranean Sea urchins in the formation of barren grounds. Estuar. Coast. Shelf Sci. 152, 73-77. doi: 10.1016/j.ecss.2014.11.023

Aguado-Giménez, F., Piedecausa, M. A., Gutiérrez, J. M., García-Charton, J. A., Belmonte, A., and García-García, B. (2012). Benthic recovery after fish farming cessation: a beyond-BACI approach. Mar. Pollut. Bull. 64, 729-738. doi: 10. 1016/j.marpolbul.2012.02.012

Aguado-Giménez, F., and Ruiz-Fernández, J. M. (2012). Influence of an experimental fish farm on the spatio-temporal dynamic of a Mediterranean maërl algae community. Mar. Environ. Res. 74, 47-55. doi: 10.1016/j.marenvres. 2011.12.003

Astruch, P., Bonhomme, P., Goujard, A., Rouanet, É, Boudouresque, C. F., Harmelin, J., et al. (2016). Provence and Mediterranean warming: the parrotfish Sparisoma cretense is coming. Rapp. Comm. Intl. Mer Médit. 41:362.

Avrani, S., Schwartz, D. A., and Lindell, D. (2012). Virus-host swinging party in the oceans: incorporating biological complexity into paradigms of antagonistic coexistence. Mob. Gen. Elem. 2, 88-95. doi: 10.4161/mge.20031

Balata, D., Piazzi, L., Nesti, U., Bulleri, F., and Bertocci, I. (2010). Effects of enhanced loads of nutrients on epiphytes on leaves and rhizomes of Posidonia oceanica. J. Sea Res. 63, 173-179. doi: 10.1016/j.seares.2009.12.001

Ballesteros, E., and Garcia Rubies, A. (1987). "La pêche aux oursins en Espagne et plus particulièrement en Catalogne," in Colloque International sur Paracentrotus lividus et les Oursins Comestibles, ed. C. F. Boudouresque (Marseille: GIS Posidonie Publications), 325-328.

Balmford, A., and Bond, W. (2005). Trends in the state of nature and their implications for human well-being. Ecol. Lett. 8, 1218-1234. doi: 10.1111/j. 1461-0248.2005.00814.x

Barber, B. J. (1997). Impacts of bivalve introductions on marine ecosystems: a review. Bull. Nation. Res. Inst. Aquac. 49, 141-153.

Barbesgaard, M. (2018). Blue growth: savior or ocean grabbing? J. Peasant Stud. 45, 130-149. doi: 10.1080/03066150.2017.1377186

Basaran, A. K., Aksu, M., and Egemen, O. (2010). Impacts of the fish farms on the water column nutrient concentration and accumulation of heavy metals in the sediments of the eastern Aegean Sea (Turkey). Environ. Monit. Assess. 162, 439-451. doi: 10.1007/s10661-009-0808-x

Basurco, B., and Lovatelli, A. (2003). The aquaculture situation in the Mediterranean Sea. Prediction for the future. Available online at: www.oceandocs.org/bitstream/handle/1834/543/basurco.pdf? sequence=1.

Belias, C., and Dassenakis, M. (2002). Environmental problems in the development of marine fish-farming in the Mediterranean Sea. Ocean Challenge 12, $11-16$.

Bertocci, I., Blanco, A., Franco, J. N., Fernández-Boo, S., and Arenas, F. (2018). Short-term variation of abundance of the purple sea urchin, Paracentrotus lividus (Lamarck, 1816), subject to harvesting in northern Portugal. Mar. Environ. Res. 141, 247-254. doi: 10.1016/j.marenvres.2018.09.017

Bertocci, I., Dominguez, R., Machado, I., Freitas, C., Domínguez Godino, J., SousaPinto, I., et al. (2014). Multiple effects of harvesting on populations of the purple sea urchin Paracentrotus lividus in north Portugal. Fish. Res. 150, 60-65. doi: 10.1016/j.fishres.2013.10.010

Bethoux, J. P. (1979). Budgets of the Mediterranean Sea. Their dependence on the local climate and on the characteristics of the Atlantic waters. Oceanol. Acta 2, $157-163$.

Bethoux, J. P., and Gentili, B. (1998). Functioning of the Mediterranean Sea: past and present changes related to freshwater input and climate change. J. Mar. Syst. $557,1-15$

Bethoux, J. P., Gentili, B., Morin, P., Nicolas, E., Pierre, C., and Ruiz-Pino, D. (1999). The Mediterranean Sea: a miniature ocean for climatic and environmental studies and a key for the climatic functioning of the North Atlantic. Prog. Oceanogr. 44, 131-146. doi: 10.1016/s0079-6611(99)00023-3

Bianchi, C. N., Azzola, A., Bertolino, M., Betti, F., Bo, M., Cattaneo-Vietti, R., et al. (2019). Consequences of the marine climate and ecosystem shift of the 1980-90s on the Ligurian Sea biodiversity (NW Mediterranean). Eur. Ecol. J. 86, 458-487. doi: $10.1080 / 24750263.2019 .1687765$
Blanfuné, A., Boudouresque, C. F., Verlaque, M., and Thibaut, T. (2016). The fate of Cystoseira crinita, a forest-forming Fucale (Phaeophyceae, Stramenopiles), in France (North Western Mediterranean Sea). Estuar. Coast. Shelf Sci. 18, 196-208. doi: 10.1016/j.ecss.2016.08.049

Blanfuné, A., Boudouresque, C. F., Verlaque, M., and Thibaut, T. (2019). The ups and downs of a canopy-forming seaweed over a span of more than one century. Sci. Rep. 9:5250.

Borja, Á, Rodríguez, J. G., Black, K., Bodoy, A., Emblow, C., Fernandes, T. F., et al. (2009). Assessing the suitability of a range of benthic indices in the evaluation of environmental impact of fin and shellfish aquaculture located in sites across Europe. Aquaculture 293, 231-240. doi: 10.1016/j.aquaculture.2009.04.037

Boudouresque, C. F. (1997). "Population dynamics of Caulerpa taxifolia in the Mediterranean, including the mechanisms of interspecific competition," in Dynamique D'espèces Marines Invasives: Application à L'expansion de caulerpa Taxifolia en Méditerranée, (Paris: Lavoisier publ.), 145-162.

Boudouresque, C. F. (1999a). "Introduced species in the Mediterranean: routes, kinetics and consequences," in Proceedings of the workshop on invasive Caulerpa species in the Mediterranean. MAP Technical Reports Series (Athens: UNEP publ.), 51-72.

Boudouresque, C. F. (1999b). "The Red Sea - Mediterranean Link: Unwanted Effects of Canals," in Invasive Species and Biodiversity Management, eds O. T. Sandlund, P. J. Schei, and A. Viken (New York, NY: Kluwer Academic publ), 213-228. doi: 10.1007/978-94-011-4523-7_14

Boudouresque, C. F. (2013). “Qu'est-ce qu'une lagune méditerranéenne?” in Les Actes des rencontres LAGUN'R. Rencontres scientifiques autour de l'étang de Berre, 14-15 March 2011 (Aix-en-Provence: GIPREB), 14-16.

Boudouresque, C. F. (2014). Insights into the diversity of the biodiversity concept. Sci. Rep. Port-Cros Natl. Park 28, 65-86.

Boudouresque, C. F. (2015). “Taxonomy and phylogeny of unicellular eukaryotes," in Environmental microbiology: Fundamentals and applications. Microbial ecology, eds J. C. Bertrand, P. Caumette, P. Lebaron, R. Matheron, P. Normand, and T. Sime-Ngando (Berlin: Springer), 191-257. doi: 10.1007/978-94-0179118-2_7

Boudouresque, C. F., Bernard, G., Bonhomme, P., Charbonnel, E., Diviacco, G., Meinesz, A., et al. (2012). Protection and Conservation of Posidonia Oceanica Meadows. Tunis: RAMOGE and RAC/SPA publ, 1-202.

Boudouresque, C. F., Bernard, G., Bonhomme, P., Charbonnel, E., Le Diréach, L., and Ruitton, S. (2007). Monitoring methods for Posidonia oceanica seagrass meadows in Provence and the French Riviera. Sci. Rep. Port.-Cros Natl. Park 22, 17-38.

Boudouresque, C. F., Bernard, G., Pergent, G., Shili, A., and Verlaque, M. (2009). Regression of Mediterranean seagrasses caused by natural processes and anthropogenic disturbances and stress: a critical review. Bot. Mar. 52, 395-418.

Boudouresque, C. F., Caltagirone, A., Lefèvre, J. R., Rico, V., and Semroud, R. (1992). "Macrozoobenthos de la réserve naturelle de Scandola (Corse, Méditerranée nord-occidentale). Analyse pluriannuelle de 'l'effet réserve," in Economic Impact of the Mediterranean Coastal Protected Areas, eds J. Olivier, N. Gerardin, Jeudy, and A. de Grissac (Hyères: Medpan Secretariat Publisher), 15-20.

Boudouresque, C. F., Caumette, P., Bertrand, J. C., Normand, P., and SimeNgando, T. (2015a). "Systematic and evolution of microorganisms: general concepts," in Environmental Microbiology: Fundamentals and Applications. Microbial Ecology, eds J. C. Bertrand, P. Caumette, P. Lebaron, R. Matheron, P. Normand, and T. Sime-Ngando (Berlin: Springer), 107-144. doi: 10.1007/ 978-94-017-9118-2_5

Boudouresque, C. F., Personnic, S., Astruch, P., Ballesteros, E., Bellan-Santini, D., Bonhomme, P., et al. (2015b). "Ecosystem-based versus species-based approach for assessment of the human impact on the Mediterranean seagrass Posidonia oceanica," in Marine Productivity: Perturbations and Resilience of Socio-Ecosystems, eds H. Ceccaldi, Y. Hénocque, Y. Koike, T. Komatsu, G. Stora, and M. H. Tusseau-Vuillemin (Berlin: Springer), 235-241. doi: 10.1007/978-3319-13878-7_25

Boudouresque, C. F., Gerbal, M., and Knoepffler-Peguy, M. (1985). Lalgue japonaise Undaria pinnatifida (Phaeophyceae, Laminariales) en méditerranée. Phycologia 24, 364-366. doi: 10.2216/i0031-8884-24-3-364.1

Boudouresque, C. F., Klein, J., Ruitton, S., and Verlaque, M. (2011). "Biological Invasion: The Thau Lagoon, a Japanese biological island in the Mediterranean Sea," in Global Change: Mankind-Marine Environment Interactions, eds H. J. 
Ceccaldi, I. Dekeyser, M. Girault, and G. Stora (Dordrecht: Springer publ.), 151-156. doi: 10.1007/978-90-481-8630-3_27

Boudouresque, C. F., and Meinesz, A. (1982). Découverte de l'herbier de posidonie. Cah. Parc Natl. Port-Cros 4, 1-79.

Boudouresque, C. F., Pergent, G., Pergent-Martini, C., Ruitton, S., Thibaut, T., and Verlaque, V. (2016). The necromass of the Posidonia oceanica seagrass meadow: fate, role, ecosystem services and vulnerability. Hydrobiologia 781, 25-42. doi: 10.1007/s10750-015-2333-y

Boudouresque, C. F., Ruitton, S., and Verlaque, M. (2005). "Large-scale disturbances, regime shift and recovery in littoral systems subject to biological invasions," in Large-scale Disturbances (Regime Shifts) and Recovery in Aquatic Ecosystems: Challenges for Management towards Sustainability, eds V. Velikova and N. Chipev (Paris: Unesco publ.), 85-101.

Boudouresque, C. F., and Verlaque, M. (2002). Biological pollution in the Mediterranean Sea: invasive versus introduced macrophytes. Mar. Pollut. Bull. 44, 32-38. doi: 10.1016/s0025-326x(01)00150-3

Boudouresque, C. F., and Verlaque, M. (2012). An overview of species introduction and invasion processes in marine and coastal lagoon habitats. Cah. Biol. Mar. 53, 309-317.

Boudouresque, C. F., and Verlaque, M. (2013). "Paracentrotus lividus," in Sea Urchins: Biology and Ecology, 3rd Edn, ed. J. M. Lawrence (Amsterdam: Elsevier), 297-327.

Boudouresque, C. F., and Verlaque, M. (2020). "Paracentrotus lividus," in Developments in Aquaculture and Fisheries Science, Vol. 43, (Amsterdam: Elsevier Publ.), 447-485.

Boyra, A., Nascimento, F. J. A., Tuya, F., Sanchez-Jerez, P., and Haroun, R. J. (2004). Impact of sea-cage fish farms on intertidal macrobenthic assemblages. J. Mar. Biol. Ass. UK 84, 665-668. doi: 10.1017/s0025315404009713h

Brault, D., and Briand, X. (1987). L'algue alimentaire humaine, perspectives de développement en France. Equinoxe 16, 4-13.

Butler, A., Vicente, N., Gaulejac, B., and de. (1993). Ecology of the pterioid bivalves Pinna bicolor Gmelin and P. nobilis L. Mar. Life 3, 37-45.

Butler, D. (2007). Ancient algal mixup sorted. Nature 396.

Cabanellas-Reboredo, M., Vázquez-Luis, M., Mourre, B., Álvarez, E., Deudero, S., Amores, Á, et al. (2019). Tracking a mass mortality outbreak of pen shell Pinna nobilis populations: a collaborative effort of scientists and citizens. Sci. Rep. 9:13355.

Cancemi, G., De Falco, G., and Pergent, G. (2000). Impact of fish farming facility on a Posidonia oceanica meadow. Biol. Mar. Mediterr. 7, 341-344.

Cancemi, G., De Falco, G., and Pergent, G. (2003). Effects of organic matter input from a fish farming facility on a Posidonia oceanica meadow. Estuar. Coast. Shelf Sci. 56, 961-969.

Carlier, A., Riera, P., Amouroux, J. M., Bodiou, J. Y., Desmalades, M., and Grémare, A. (2009). Spatial heterogeneity in the food web of a heavily modified Mediterranean coastal lagoon: stable isotope evidence. Aquat. Biol. 5, 167-179. doi: 10.3354/ab00147

Carlton, J. T. (1996). Biological invasions and cryptogenic species. Ecology 77, 1653-1655. doi: 10.2307/2265767

Catanese, G., Grau, A., Valencia, J. M., Garcia-March, J. R., Vásquez-Luis, M., Alvarez, E., et al. (2018). Haplosporidium pinnae sp. nov., a haplosporidan parasite associated with mass mortalities of the fan mussel, Pinna nobilis, in the Western Mediterranean Sea. J. Invertebr. Pathol. 157, 9-24. doi: 10.1016/j. jip.2018.07.006

Cecere, E., Petrocelli, A., and Saracino, O. D. (2000). Undaria pinnatifida (Fucophyceae, Laminariales) spread in the central Mediterranean: its occurrence in the Mar Piccolo of Tarento (Ionian Sea, southern Italy). Cryptog. Algol. 21, 305-309. doi: 10.1016/s0181-1568(00)00113-6

Charbonnier, D. (1990). Pêche et Aquaculture en Méditerranée. État actuel et Perspectives. Paris: Economica.

Clavero, M., and Garcia-Berthou, E. (2005). Invasive species are a leading cause of animal extinctions. Trends Ecol. Evol. 20:110. doi: 10.1016/j.tree.2005.01.003

Combes, C. (1995). Les Interactions Durables. Ecologie et Évolution du Parasitisme. Paris: Masson publ.

Combes, C. (2001). Les Associations du Vivant. Lart d'être Parasite. Paris: Flammarion publ.

Comps, M. (1983). Les infections virales associées aux épizooties des huîtres du genre Crassostrea. Rapp. P.-V. Réun. Cons. Intl. Explor. Mer Medit. 182, 137-139.
Comps, M., Bonami, J. R., Vago, C., and Campillo, A. (1976). Virus-disease of portuguese oyster (Crassostrea angulata Lmk). C. R. Acad. Sci. Paris D 282, 1991-1993.

Comps, M., and Duthoit, J. L. (1976). Infection virale associée à la 'maladie des branchies' de l'huître portugaise Crassostrea angulata Lmk. C. R. Acad. Sci. Paris D 283, 1595-1596.

Cook, E. J., Black, K. D., Sayer, M. D. J., Cromey, C. J., Angel, D. L., Spanier, E., et al. (2006). The influence of caged mariculture on the early development of sublittoral fouling communities: a pan-European study. ICES J. Mar. Sci. 63, 637-649. doi: 10.1016/j.icesjms.2005.12.007

Couvray, S. (2014). Étude de la Dynamique de Populations d'oursins Comestibles Paracentrotus lividus (Lamarck, 1816) en zone pêchée et anthropisée: évaluation de l'efficacité et de l'impact d'opérations de lâchers de juvéniles pour le repeuplement, $\mathrm{Ph}$. D. Thesis. Université de Toulon, Toulon.

Couvray, S., Miard, T., Bunet, R., Martin, Y., Grillasca, J. P., Bonnefont, J. L., et al. (2015). Experimental release of juvenile sea urchins (Paracentrotus lividus) in exploited sites along the French Mediterranean coast. J. Shellfish Res. 34, 555-563. doi: 10.2983/035.034.0240

Darriba, S. (2017). First haplosporidan parasite reported infecting a member of the superfamily Pinnoidae (Pinna nobilis) during a mortality event in Alicante (Spain, Western Mediterranean). J. Invertebr. Pathol. 148, 14-19. doi: 10.1016/ j.jip.2017.05.006

De Biasi, A. M., Pacciardi, L., and Piazzi, L. (2016). An asymmetrical sampling design as a tool for sustainability assessment of human activities in coastal systems: a fish farming study case. Mar. Biol. Res. 12, 958-968. doi: 10.1080/ 17451000.2016.1225958

De Casabianca, M. L., Rabotin, M., and Rigault, R. (2003). Preliminary results on eelgrass regression and red seaweed dominance under increasing eutrophication (Thau Lagoon, France). Acta Adriatica 44, 33-40.

de la Uz, S., Carrasco, J. F., Rodríguez, C., and López, J. (2018). Evaluation of tagging and substrate refuges in release of juvenile sea urchins. Reg. Stud. Mar. Sci. 23, 8-11. doi: 10.1016/j.rsma.2018.02.008

Delgado, O., Grau, A., Pou, S., Riera, S., Massuti, C., Zabala, M., et al. (1997). Seagrass regression caused by fish cultures in Fornells Bay (Menorca, Western Mediterranean). Oceanol. Acta 20, 557-563.

Delgado, O., Ruiz, J., Pérez, M., Romero, J., and Ballesteros, E. (1999). Effects of fish farming on seagrass (Posidonia oceanica) in a Mediterranean bay: seagrass decline after organic loading cessation. Oceanol. Acta 32, 109-117. doi: 10.1016/ s0399-1784(99)80037-1

Deslous-Paoli, J. M., Mazouni, N., Souchu, P., Landrein, S., Pichot, P., and Juge, C. (1993). "Oyster farming impact on the environment of a Mediterranean lagoon (THAU) (Preliminary results of the OXYTHAU programme)," in Bivalve Filter Feeders, ed. R. F. Dame (Berlin: Springer), 519-521. doi: 10.1007/978-3-64278353-1_18

Dimech, M., Borg, J. A., and Schembri, P. J. (2000a). Structural changes in Posidonia oceanica meadow exposed to a pollution gradient from a marine fish-farm in Malta (central Mediterranean). Biol. Mar. Mediterr. 7, 361-364.

Dimech, M., Borg, J. A., and Schembri, P. J. (2000b). The effects of a marine fish-farm on the species richness and abundance of molluscs, decapods and echinoderms associated with a Posidonia oceanica meadow in Malta (central Mediterranean). Biol. Mar. Mediterr. 7, 357-360.

Dimech, M., Borg, J. A., and Schembri, P. J. (2002). Changes in the structure of a Posidonia oceanica meadow and in the diversity of associated decapod, mollusc and echinoderm assemblages, resulting from input of waste from a marine fish farm (Malta, central Mediterranean). Bull. Mar. Sci. 71, 1309-1321.

Duchaud, S., Durieux, E. D., Coupe, S., Pasqualini, V., and Ternengo, S. (2018). Spatio-temporal patterns based on demographic and genetic diversity of the purple sea urchin Paracentrotus lividus in the area around Corsica (Mediterranean Sea). Mediterr. Mar. Sci. 19, 620-641.

Elton, C. S. (1958). The Ecology of Invasions by Animals and Plants. Methuen, MA: Methuen publ.

FAO (2019). Fishery and Aquaculture Statistics. Global aquaculture production 1950-2017 (FishstatJ). Updated 2019. Rome: FAO Fisheries and Aquaculture Department [online]. Available online at: www.fao.org/fishery/statistics/software/fishstatj/en (accessed 5 December 2019).

Farmer, D. M., and Armi, L. (1988). The flow of Atlantic water through the strait of gibraltar. Prog. Oceanogr. 21, 1-105. 
Floc'h, J. Y., Pajot, R., and Mouret, V. (1996). Undaria pinnatifida (Laminariales, Phaeophyta) 12 years after its introduction into the Atlantic Ocean. Hydrobiologia 32, 217-222. doi: 10.1007/bf00047810

Fraschetti, S., Terlizzi, A., Garnieri, G., Pizzolante, F., D’ambrosio, P., Maiorano, P., et al. (2011). Effects of unplanned development on marine biodiversity: a lesson from Albania (central Mediterranean Sea). J. Coastal Res. 58, 106-115. doi: 10.2112/si_58_10

Fuhrman, J. A. (1999). Marine viruses and their biogeochemical and ecological effects. Nature 399, 541-548. doi: 10.1038/21119

Gaertner-Mazouni, N., and De Wit, R. (2012). Exploring new issues for coastal lagoons monitoring and management. Estuar. Coast. Shelf Sci. 114, 1-6. doi: 10.1016/j.ecss.2012.07.008

Giakoumi, S., Halpern, B. S., Michel, L. N., Gobert, S., Sini, M., Boudouresque, C. F., et al. (2015). Towards a framework for assessment and management of cumulative human impacts on marine food webs. Conserv. Biol. 29, 1228-1234. doi: $10.1111 /$ cobi.12468

Goldburg, R., and Naylor, R. (2005). Future seascapes, fishing and fish farming. Front. Ecol. Environ. 3, 21-28. doi: 10.1890/1540-92952005003[0021:FSFAFF] 2.0.CO;2

González-Wangüemert, M., Basso, L., Balau, A., Costa, J., Renault, L., Serrão, E. A., et al. (2018). Gene pool and connectivity patterns of Pinna nobilis in the Balearic Islands (Spain, Western Mediterranean Sea): implications for its conservation through retocking. Aq. Cons. Mar. Freshw. Ecos. 29, 175-188. doi: $10.1002 /$ aqc. 2976

Goulletquer, P. (2005). "Cultured Aquatic Species Information Programme. Ruditapes philippinarum," in Cultured Aquatic Species Information Programme (Rome: FAO Fisheries and Aquaculture Department). Available online at: http: //www.fao.org/fishery/culturedspecies/Ruditapes_philippinarum/en (accessed December 1, 2019).

Grigorakis, K., and Rigos, G. (2011). Aquaculture effects on environmental and public welfare - the case of Mediterranean mariculture. Chemosphere 85, 699-919.

Gros, C. (1978). Le genre Cystoseira sur la côte des Albères. Répartition Écologie - Morphogénèse. $\mathrm{PhD}$ thesis., Université Pierre et Marie Curie, Paris.

Guidetti, P., Terlizzi, A., and Boero, F. (2004). Effects of the edible sea urchin, Paracentrotus lividus, fishery along the Apulian rocky coast (SE Italy, Mediterranean Sea). Fish. Res. 66, 287-297. doi: 10.1016/s0165-7836(03)002066

Hall-Spencer, J., White, N., Gillespie, E., Gillham, K., and Foggo, A. (2006). Impact of fish farms on maerl beds in strongly tidal areas. Mar. Ecol. Progr. Ser. 326, 1-9. doi: $10.3354 /$ meps 326001

Harmelin, J. G., Bouchon, C., and Hong, J. S. (1981). Impact de la pollution sur la distribution des échinodermes des substrats durs en Provence (Méditerranée Nord-occidentale). Téthys 10, 13-36.

Hilborn, R., Amoroso, R. O., Anderson, C. M., Baum, J. K., Branch, T. A., Costello, C., et al. (2020). Effective fisheries management instrumental in improving fish stock status. Proc. Natl. Acad. Sci. U.S.A. 117, 2218-2224.

Holmer, M., Argyrou, M., Dalsgaard, T., Danovaro, R., Diaz-Almela, E., Duarte, C. M., et al. (2008). Effects of fish farm waste on Posidonia oceanica meadows: synthesis and provision of monitoring and management tools. Mar. Pollut. Bull. 56, 1618-1629. doi: 10.1016/j.marpolbul.2008.05.020

Holmer, M., Pérez, M., and Duarte, C. M. (2003). Benthic primary producers - a neglected environmental problem in Mediterranean maricultures? Mar. Pollut. Bull. 46, 1372-1376. doi: 10.1016/s0025-326x(03)00396-5

Holon, F., Marre, G., Parravicini, V., Mouquet, N., Bockel, T., Descamp, P., et al. (2018). A predictive model based on multiple coastal anthropogenic pressures explains the degradation status of a marine ecosystem: implications for management and conservation. Biol. Conserv. 222, 125-135. doi: 10.1016/j. biocon.2018.04.006

IFFO (2019). The Marine Ingredients Organisation. Available online at: www.iffo.net/position-paper/aquaculture-growth-putting-pressure-feed-fish (accessed 27 November 2019).

Israel, D., Lupatsch, I., and Angel, D. L. (2019). Testing the digestibility of seabram waste in three candidates for integrated multi-trophic aquaculture: grey mullet, sea urchin and sea cucumber. Aquaculture 510, 364-370. doi: 10.1016/j.aquaculture.2019.06.003
Jacquet, J., and Pauly, D. (2008). Funding priorities: big barriers to smallscale fisheries. Conserv. Biol. 22, 832-835. doi: 10.1111/j.1523-1739.2008. 00978.x

Kaiser, M. J., and Hiddink, J. G. (2007). Food subsidies from fisheries to continental shelf benthic scavengers. Mar. Ecol. Prog. Ser. 350, 267-276. doi: 10.3354/ meps07194

Kalavrouziotis, I. K., Kokkinos, P., Oron, G., Fatone, F., Bolzonella, D., Vatyliotou, M., et al. (2015). Current status in wastewater treatment, reuse and research in some Mediterranean countries. Desalin. Wat. Treat. 53, 2015-2030. doi: 10.1080/19443994.2013.860632

Karachle, P. K., Angelidis, A., Apostolopoulos Gayas, D., Ballesteros, M., Bonnici, C., Brodersen, M. M., et al. (2016). New mediterranean biodiversity records (March 2016). Mediterr. Mar. Sci. 17, 230-252.

Kawai, H., Kogishi, K., Hanyuda, T., Arai, S., Gurgel, F., Nelson, W., et al. (2016). Phylogeographic analysis of the brown alga Cutleria multifida (Tilopteridales), Phaeophyceae) suggests a complicated introduction history. Phycol. Res. 64, 3-10. doi: 10.1111/pre.12113

Khadr, A. M. (2003). "Evolution of the Nile deposits input during the quaternary and its effect on Egyptian coastline," in Human Records of Recent Geological Evolution in the Mediterranean Basin - Historical and Archeological Evidence, CIESM Workshop monographs 24, ed. F. Briand (Monaco: CIESM publ.), 25-28.

Kletou, D., Kleitou, P., Savva, I., Attrill, M. J., Antoniou, C., and Hall-Spencer, J. M. (2018). Seagrass recovery after fish farm relocation in the eastern Mediterranean. Mar. Environ. Res. 140, 221-233. doi: 10.1016/j.marenvres. 2018.06.007

Kousoulaki, K., Sæther, B. S., Albrektsen, S., and Noble, C. (2015). Review of European sea bass (Dicentrarchus labrax), Linnaeus, 1758) nutrition and feed management: a practical guide for optimizing feed formulation and farming protocols. Aquacult. Nutr. 21, 129-151. doi: 10.1111/anu.12233

Kružić, P. (2008). Variations in Posidonia oceanica meadow structure along the coast of the Dugi Otok Island (eastern Adriatic Sea). J. Mar. Biol. Ass. U.K. 88, 883-892. doi: $10.1017 / \mathrm{s} 0025315408001410$

Kuo, J., Hartog, C., and den. (2000). Seagrasses a profile of an ecological group. Biol. Mar. Mediterr. 7, 3-17.

Kušpilić, G., Tièina, V., Matijević, S., Skejić, S., Antolić, B., Grubelić, I., et al. (2007). "Impact of fish farming on marine ecosystems. Croatian experiences," in Impact of Mariculture on Coastal Ecosystems: CIESM Workshop Monographs, Vol. 32, ed. F. Briand (Monaco: CIESM), 29-34.

Le Gouvello, R., and Simard, F. (eds) (2017). Durabilité des Aliments Pour le Poisson en Aquaculture: Réflexions et recommandations sur les Aspects Technologiques, Économiques, Sociaux et Environnementaux. Gland and Paris: UICN.

Ledireac'h, J. P. (1987). "La pêche des oursins en Méditerranée: historique, techniques, législation, production," in Colloque International sur Paracentrotus lividus et les Oursins Comestibles, ed. C. F. Boudouresque (Marseille: GIS Posidonie Publications), 335-362.

Ledireac'h, J. P., Boudouresque, C. F., Antolić, B., Kocataş, A., Panayotidis, P., Pancucci, A., et al. (1987). "Rapport sur l'exploitation des oursins en Méditerranée," in Colloque International Sur Paracentrotus Lividus et Les Oursins Comestibles, ed. C. F. Boudouresque (Marseille: GIS Posidonie Publications), 329-334.

Lejeusne, C., Chevaldonné, P., Pergent-Martini, C., Boudouresque, C. F., and Perez, T. (2010). Climate change effects on a miniature ocean: the highly diverse, highly impacted Mediterranean Sea. Trends Ecol. Evol. 25, 250-260. doi: 10. 1016/j.tree.2009.10.009

Ling, S. D., Scheibling, R. E., Rassweiler, A., Johnson, C. R., Shears, N., Connell, S. D., et al. (2015). Global regime shift of catastrophic sea urchin overgrazing. Philos. Trans. R. Soc. B 370, 1-10.

Loi, B., Guala, I., Pires, da Silva, R., Brundu, G., Baroli, M., et al. (2017). Hard time to be parents? Sea urchin fishery shifts potential reproductive contribution of population onto the shoulders of the young adults. PeerJ 5:e3067. doi: 10.7717/ peerj. 3067

Loya, Y., Lubinevsky, H., Rosenfeld, M., and Kramarski-Winter, E. (2004). Nutrient enrichment caused by in situ fish farms at Eilat, Red Sea is detrimental to coral reproduction. Mar. Pollut. Bull. 49, 344-353. doi: 10.1016/j.marpolbul.2004.06. 011

Lumare, F. (1983). Italian valliculture and its future development. Rapp. Comm. Int. Mer Méditerr. 28, 85-89. 
Lundälv, T., Larsson, C. S., and Axelsson, L. (1986). Long-term trends in algaldominated rocky subtidal communities on the Swedish west coast - A transitional system? Hydrobiologia 142, 81-95. doi: 10.1007/978-94-009-40499_8

Machias, A., Karakassis, I., Lobropoulou, M., Somarakis, S., Papadopoulou, K. N., and Papaconstantinou, C. (2004). Changes in wild fish assemblages after the establishment of a fish farming zone in an oligotrophic marine ecosystem. Estuar. Coast. Shelf Sci. 60, 771-779. doi: 10.1016/j.ecss.2004.03.014

Machias, A., Karakassis, I., Papadopoulou, K. N., Smith, C. J., and Somarakis, S. (2005). Response of demersal fish communities to the presence of fish farms. Mar. Ecol. Prog. Ser. 288, 241-250. doi: 10.3354/meps288241

Marbà, N., Santiago, R., Díaz-Almela, E., Álvarez, E., and Duarte, C. M. (2006). Seagrass (Posidonia oceanica) vertical growth as an early indicator of fish farmderived stress. Estuar. Coast. Shelf Sci. 67, 475-483. doi: 10.1016/j.ecss.2005.11. 034

Marchini, A., Ferrario, J., Sfriso, A., and Occhipinti-Ambroggi, A. (2015). Current status and trends of biological invasions in the Lagoon of Venice, a hotspot of marine NIS introductions in the Mediterranean Sea. Biol. Inv. 17, 2943-2962. doi: 10.1007/s10530-015-0922-3

Marino, G. (2011). "Sustainable aquaculture: bioecological aspects," in The State of Italian Marine Fisheries and Aquaculture, eds S. Cataudella and M. Spagnolo (Rome: Ministero delle Politiche Agricole, Alimentari e Forestali - MiPAAF), 281-286.

Massa, F., Onofri, L., and Fezzardi, D. (2017). "Aquaculture in the Mediterranean and the Black Sea: a blue growth perspective," in Hanbook on the Economics and Management of Sustainable Oceans, eds P. A. L. D. Bunes, L. E. Svennson, and A. Markadya (Cheltenham: Edward Elgar Publishing), 93-122.

Mazzola, A. (1992). Allochtonous species and aquaculture. Boll. Mus. Ist. Biol. Univ. Genova 5, 235-246.

Mendez, S., Pergent, G., and Pergent-Martini, C. (1997). "Impact of fish farming on coastal ecosystems," in Proceedings of the Third International Conference on the Mediterranean Coastal Environment, ed. E. Özhan (Ankara: MEDCOAST Secretariat, Middle East Technical University Publ), 197-211.

Millot, C., and Taupier-Letage, I. (2005). Circulation of the Mediterranean Sea. Handbook Env. Chem. 5(K), 29-66. doi: 10.1007/b107143

Miossec, L., Le Deuff, R. M., and Goulletquer, P. (2009). Alien species alert: Crassostrea gigas (Pacific oyster). ICES Cooperat. Res. Rep. 299, 1-42.

Molinier, R., and Picard, J. (1952). Recherches sur les herbiers de phanérogames marines du littoral méditerranéen français. Ann. Inst. Océanogr. 2, 157-234.

Mylonas, C. C., De la Gándara, F., Corriero, A., and Belmonte Ríos, A. (2010). Atlantic bluefin tuna (Thunnus thynnus) farming and fattening in the Mediterranean Sea. Rev. Fish Sci. 18, 266-280. doi: 10.1080/10641262.2010. 509520

Navarrete-Mier, F., Sanz-Lazaro, C., and Marin, A. (2011). Does bivalve mollusc polyculture reduce marine fin fish farming environmental impact? Aquaculture 306, 101-107. doi: 10.1016/j.aquaculture.2010.06.013

Navarro, L., Ballesteros, E., Linares, C., and Hereu, B. (2011). Spatial and temporal variability of deep-water algal assemblages in the Northwesten Mediterranean: the effects of an exceptional storm. Estuar. Cost. Shelf Sci. 95, 52-58. doi: 10.1016/j.ecss.2011.08.002

Ocaña, Ó, Afonso-Carillo, J., and Ballesteros, E. (2016). Massive proliferation of a dictyotalean species (Phaeophyceae, Ochrophyta) through the Strait of Gibraltar (Research note). Rev. Acad. Canar. Cienc. 28, 165-170.

Occhipinti Ambroggi, A. (2001). Transfer of marine organisms: a challenge to the conservation of coastal biocoenoses. Aquat. Conserv. Mar. Freshw. Ecosyst. 11, 243-251. doi: 10.1002/aqc.450

Occhipinti Ambrogi, A. (2000). Biotic invasions in a Mediterranean lagoon. Biol. Inv. 2, 165-176.

Orth, R. J., Carruthers, T. J. B., Dennison, W. B., Duarte, C. M., Fourqurean, J. W., Heck, K. L. Jr., et al. (2006). A global crisis for seagrass ecosystems. BioScience 56, 987-996.

Pauly, D., Ulman, A., Piroddi, C., Bultel, E., and Coll, M. (2014). 'Reported' versus 'likely' fisheries catches of four Mediterranean countries. Sci. Mar. 78, 11-17. doi: 10.3989/scimar.04020.17a

Pauly, D., Watson, R., and Alder, J. (2005). Global trends in world fisheries: impacts on marine ecosystems and food security. Philos. Trans. R. Soc. B 36, 5-12. doi: $10.1098 /$ rstb.2004.1574
Pauly, D., and Zeller, D. (2016). Catch reconstructions reveal that global marine fisheries catches are higher than reported and declining. Nat. Comm. 7:10244.

Pérès, J. M. (1982). "Structure and dynamics of assemblages in the benthal," in Marine Ecology, Vol. 5, ed. O. Kinne (Chichester: John Wiley \& sons Ltd publ.), 119-185.

Pérès, J. M., and Picard, J. (1964). Nouveau manuel de bionomie benthique de la mer Méditerranée. Rec. Trav. Stat. Mar. Endoume 31, 3-137.

Pérez, M., García, T., Invers, O., and Ruiz, J. M. (2008). Physiological responses of the seagrass Posidonia oceanica as indicators of fish farm impact. Mar. Pollut. Bull. 56, 869-879. doi: 10.1016/j.marpolbul.2008.02.001

Pergent, C. (2018). Grande nacre: conséquences pour notre façade suite aux mortalités massives en Espagne. La Lettre d'Information des Gestionnaires d'AMP de la Façade Méditerr. 7, 12-13.

Pergent, G., Bazairi, H., Bianchi, C. N., Boudouresque, C. F., Buia, M. C., Clabaut, P., et al. (2012). Mediterranean Seagrass Meadows: Resilience and Contribution to Climate Change Mitigation. A Short Summary. Gland: IUCN publ.

Pergent, G., Mendez, S., Pergent-Martini, C., and Pasqualini, V. (1999). Preliminary data on the impact of fish farming facilities on Posidonia oceanica meadows in the Mediterranean. Oceanol. Acta 22, 95-107. doi: 10.1016/s03991784(99)80036-x

Pergent, P., Bazairi, H., Bianchi, C. N., Boudouresque, C. F., Buia, M. C., Calvo, S., et al. (2014). Climate change and Mediterranean seagrass meadows: a synopsis for environmental managers. Medit. Mar. Sci. 15, 462-473.

Pergent-Martini, C., Boudouresque, C. F., Pasqualini, V., and Pergent, G. (2006). Impact of fish farming facilities on Posidonia oceanica meadows: a review. Mar. Ecol. 27, 310-319. doi: 10.1111/j.1439-0485.2006.00122.x

Personnic, S., Boudouresque, C. F., Astruch, P., Ballesteros, E., Blouet, S., BellanSantini, D., et al. (2014). An ecosystem-based approach to assess the status of a Mediterranean ecosystem, the Posidonia oceanica seagrass meadow. PLoS ONE 9:e98994. doi: 10.1371/journal.pone.0098994

Petrocelli, A., Cecere, E., and Rubino, F. (2019). Successions of phytobenthos species in a Mediterranean transitional water system: the importance of long term observations. Nat. Conserv. 34, 217-246. doi: 10.3897/natureconservation. 34.30055

Petrocelli, A., Cecere, E., and Verlaque, M. (2013). Alien marine macrophyes in transitional water systems: new entries and reappearances in a Mediterranean coastal basin. BioInvasions Rec. 2, 177-184. doi: 10.3391/bir.2013.2.3.01

Piazzi, L., and Balata, D. (2009). Invasion of alien macroalgae in different Mediterranean habitats. Biol. Inv. 11, 193-204. doi: 10.1007/s10530-008-9224-3

Piazzi, L., and Ceccherelli, G. (2002). Effects of competition between two introduced Caulerpa. Mar. Ecol. Prog. Ser. 225, 189-195. doi: 10.3354/ meps 225189

Piazzi, L., Cecchi, E., Cinti, M. F., Stipcich, P., and Ceccherelli, G. (2019). Impact assessment of fish cages on coralligenous reefs through the use of the STAR sampling procedure. Medit. Mar. Sci. 20, 627-635.

Piazzi, L., and Cinelli, F. (2003). Evaluation of benthic macroalgal invasion in a harbour area of the western Mediterranean Sea. Eur. J. Phycol. 38, 223-231. doi: 10.1080/1364253031000136358

Piquion, J. C. (1985). Aquaculture: lutte contre les compétiteurs. Equinoxe 3, 27-31. Piroddi, C., Gristina, M., Zylich, K., Greer, K., Ulman, A., Zeller, D., et al. (2015). Reconstruction of Italy's marine fisheries removals and fishing capacity. Fish. Res. 172, 137-147. doi: 10.1016/j.fishres.2015.06.028

Plus, M., Chapelle, A., Lazure, P., Auby, I., Levavasseur, G., Verlaque, M., et al. (2003). Modelling of oxygen and nitrogen cycling as a function of macrophyte community in the Thau lagoon. Cont. Shelf Res. 23, 1877-1898. doi: 10.1016/j. csr.2003.03.001

Por, F. D. (1978). Lessepsian Migrations. The influx of Red Sea Biota into the Mediterranean by Way of the Suez Canal. Berlin: Springer publ.

Por, F. D. (1990). Lessepsian migrations. An appraisal and new data. Bull. Inst. Océanogr. 7, 1-10.

Prado, P., Alcoverro, T., and Romero, J. (2008). Seasonal response of Posidonia oceanica epiphyte assemblages to nutrient increase. Mar. Ecol. Prog. Ser. 359, 89-98. doi: 10.3354/meps07438

Pranovi, F., Franceschini, G., Casale, M., Zucchetta, M., Torricelli, P., and Giovanardi, O. (2006). An ecological imbalance induced by a non-native species: the Manila clam in the Venice Lagoon. Biol. Inv. 8, 595-609. doi: 10.1007/s10530-005-1602-5 
Pranovi, F., Libralato, S., Raicevich, S., Granzotto, A., Pastres, R., and Giovanardi, O. (2003). Mechanical clam dredging in Venice Lagoon: ecosystem effects evaluated with a trophic mass-balance model. Mar. Biol. 143, 393-403. doi: 10.1007/s00227-003-1072-1

Puhr, K., and Pikelj, K. (2012). The effect of in situ shading on a Posidonia oceanica meadow situated within a fish farm induced moderately nutrient enriched environment. Mar. Pollut. Bull. 64, 1537-1548. doi: 10.1016/j.marpolbul.2012. 05.022

Ribera, M. A., and Boudouresque, C. F. (1995). "Introduced marine plants, with special reference to macroalgae: mechanisms and impact", in Progress in Phycological Research, eds F.E. Round and D.J. Chapman (Bristol: Biopress Ltd publ.) 11, 187-268.

Rodellas, V., Garcia-Orellana, J., Masqué, P., Feldman, M., and Weinstein, Y. (2015). Submarine groundwater discharge as a major source of nutrients to the Mediterranean Sea. Proc. Natl. Acad. Sci. U.S.A. 112, 3926-3930. doi: 10.1073/ pnas. 1419049112

Romero, J., Perez, M., Alcoverro, T., Mateo, M. A., and Sanchez-Lizaso, J. L. (1998). Production ecology of Posidonia oceanica (L.) Delile meadows in Nueva Tabarca marine Reserve: growth, biomass and nutrient stocks along a bathymetric gradient. Oecol. Aquat. 11, 111-121.

Rouanet, E., Trigos, S., and Vicente, N. (2015). From youth to death of old age: the 50-year story of a Pinna nobilis fan mussel population at Port-Cros Island (PortCros National Park, Provence, Mediterranean Sea). Sci. Rep. Port-Cros Nation. Park 29, 209-222.

Rountos, K. J., Peterson, B. J., and Karakassis, I. (2012). Indirect effects of fish cage aquaculture on shallow Posidonia oceanica seagrass patches in coastal Greek waters. Aquac. Environ. Interact. 2, 105-115. doi: 10.3354/aei00037

Ruesink, J. L., Lenihan, H. S., Trimble, A. C., Heiman, K. W., Micheli, F., Byers, J. E., et al. (2005). Introduction of non-native oysters: ecosystem effects and restoration implications. Ann. Rev. Ecol. Evol. Syst. 36, 643-689. doi: 10.1146/ annurev.ecolsys.36.102003.152638

Ruiz, J. M., Larco-Méndez, C., and Sánchez-Lizaso, J. L. (2010). Remote influence of off-shore fish farm waste on Mediterranean seagrass (Posidonia oceanica) meadows. Mar. Envriron. Res. 69, 118-126. doi: 10.1016/j.marenvres.2009.09. 002

Ruiz, J. M., Pérez, M., and Romero, J. (2001). Effects of fish farm loadings on seagrass (Posidonia oceanica) distribution, growth and photosynthesis. Mar. Pollut. Bull. 42, 749-760. doi: 10.1016/s0025-326x(00)00215-0

Ruiz, J. M., and Romero, J. (2001). Effects of in situ experimental shading on the Mediterranean seagrass Posidonia oceanica. Mar. Ecol. Prog. Ser. 215, 107-120. doi: $10.3354 /$ meps 215107

Ruiz-Fernandez, J. M. (2000). Respuesta de la Fanerógama Marina Posidonia oceanica (L.) Delile a Perturbaciones Antrópicas. Murcia: Mem. Doct. Biol. Univ., 1-212.

Salvi, D., and Mariottini, P. (2017). Molecular taxonomy in 2D: a novel ITS2 rRNA sequence structure approach guides the description of the oysters' subfamily Saccostreinae and the genus Magallana (Bivalvia: Ostreidae). Zool. J. Linn. Soc. $179,263-276$.

Sánchez-García, N., Raga, J. A., and Montero, F. E. (2014). Risk assessment for parasites in cultures of Diplodus puntazzo (Sparidae) in the Western Mediterranean: prospects of cross infection with Sparus aurata. Vet. Parasitol. 204, 120-133. doi: 10.1016/j.vetpar.2014.05.013

Sanz-Lázaro, C., Belando, M. D., Marín-Guirao, L., Navarette-Mier, F., and Marín, A. (2011). Relationship between sedimentation rates and benthic impact on Maërl beds derived from fish farming in the Mediterranean. Mar. Environ. Res. 71, 22-30. doi: 10.1016/j.marenvres.2010.09.005

Sarà, G., Scilipoti, D., Milazzo, M., and Modica, A. (2006). Use of stable isotopes to investigate dispersal of waste from fish farms as a function og hydrodynamics. Mar. Ecol. Prog. Ser. 313, 261-270. doi: 10.3354/meps313261

Sartori, D., Pellegrini, D., Macchia, S., and Gaion, A. (2016). Can echinoculture be a feasible and effective activity? Analysis of fast reliable breeding conditions to promote gonadal growth and sexual maturation in Paracentrotus lividus. Aquaculture 451, 39-46. doi: 10.1016/j.aquaculture.2015.08.037

Sartori, D., Scuderi, A., Sansone, G., and Gaion, A. (2015). Echinoculture: the rearing of Paracentrotus lividus in a recirculating aquaculture system Experiments of artificial diets for the maintenance of sexual maturation. Aquact. Int. 23, 111-125. doi: 10.1007/s10499-014-9802-6
Schmitz, D. C., and Simberloff, D. (1997). Biological invasions: a growing threat. Issues Sci. Technol. 13, 33-40.

Segovia-Viadero, M., Serrão, E. A., Canteras-Jordana, J. C., and GonzalezWangüemert, M. (2016). Do hatchery-reared sea urchins pose a threat to genetic diversity in wild populations? Heredity 116, 378-383. doi: 10.1038/hdy. 2015.109

Sempere-Valverde, J., García-Gómez, J. C., Ostalé-Valriberas, E., Martínez, M., Olaya-Ponzone, L., González, A. R., et al. (2019). "Expansion of the exotic brown alga Rugulopteryx okamurae (E.Y. Dawson) I.K. Hwang, W.J. Lee \& H.S. Kim in the Strait of Gibraltar," in Proceedings of the 1st Mediterranean Symposium on the Non-Indigenous Species (Antalya, Turkey, 17-18 January 2019), eds H. Langar and A. Ouerghi (Tunis: SPA/RAC publ.), 107-108.

Sfriso, A., Buosi, A., and Sfriso, A. A. (2014). On the occurrence of Uronema marinum Womersley (Chaetophorales, Chlorophyta) in the north-western lagoons of the Adriatic Sea, Mediterranean Sea (Italy). Medit. Mar. Sci. 15, 101-105.

Sfriso, A., Buosi, A., Wolf, M. A., and Sfriso, A. A. (2020). Invasion of alien macroalgae in the Venice lagoon, a pest or a resource? Aquat. Inv. 15. (in press). Available online at: https://www.reabic.net/aquaticinvasions/2020/ ACCEPTED/AI_2020_Sfriso_etal_correctedproof.pdf

Sfriso, A., Wolf, M. A., Maistro, S., Sciuto, K., and Moro, I. (2012). Spreading and autoecology of the invasive species Gracilaria vermiculophylla (Gracilariales, Rhodophyta) in the lagoons of north-western Adriatic Sea (Mediterranean Sea, Italy). Estuar. Coast. Shelf Sci. 114, 192-198. doi: 10.1016/j.ecss.2012.07.024

Sharaf, and El Din, S. H. (1977). Effect of the aswan high dam on the nile flood and on the estuarine and coastal circulation pattern along the mediterranean Egyptian coast. Limnol. Oceanogr. 22, 194-207. doi: 10.4319/lo.1977.22.2. 0194

Shpigel, M., Shauli, L., Odintsov, V., Ben-Ezra, D., Neori, A., and Guttman, L. (2018). The sea urchin, Paracentrotus lividus, in an integrated multi-trophic aquaculture (IMTA) system with fish (Sparus aurata) and seaweed (Ulva lactuca): nitrogen partitioning and proportional configurations. Aquaculture 490, 260-269. doi: 10.1016/j.aquaculture.2018.02.051

Sindermann, C. J. (1992). Disease risks associated with importation of nonindigenous marine animals. Mar. Fish. Rev. 54, 1-10.

Soliman, N. F., and Yacout, D. M. M. (2016). Aquaculture in Egypt: status, constraints and potentials. Aquacult. Int. 24, 1201-1227. doi: 10.1007/s10499016-9989-9

Stanley, D. J. (1993). "Nile Delta: recent geological evolution and human impact," in Pour qui la Méditerranée au $21^{\circ}$ siècle? Le système Littoral Méditerranéen, Colloque Scientifique OKEANOS, Montpellier, 231-234.

Stipa, P., and Angelini, M. (2005). Cultured Aquatic Species Information Programme, Argyrosomus regius. Rome: FAO Fisheries and Aquaculture Department.

Thibaut, T., Blanfuné, A., Boudouresque, C. F., Cottalorda, J. M., Hereu, B., Susini, M. L., et al. (2016). Unexpected temporal stability of Cystoseira and Sargassum forests in Port-Cros, one of the oldest Mediterranean marine National Parks. Cryptog. Algol. 37, 61-90. doi: 10.7872/crya/v37.iss1.2016.61

Thibaut, T., Blanfuné, A., Boudouresque, C. F., Personnic, S., Ruitton, R., Ballesteros, E., et al. (2017). An ecosystem-based approach to assess the status of Mediterranean algae-dominated shallow rocky reefs. Mar. Pollut. Bull. 117, 311-329. doi: 10.1016/j.marpolbul.2017.01.029

Thibaut, T., Blanfuné, A., Boudouresque, C. F., and Verlaque, M. (2015). Decline and local extinction of Fucales in the French Riviera: the harbinger of future extinctions? Mediterr. Mar. Sci. 16, 206-224.

Thibaut, T., Blanfuné, A., Markovic, L., Verlaque, M., Boudouresque, C. F., Perret-Boudouresque, M., et al. (2014). Unexpected abundance and long-term relative stability of the brown alga Cystoseira amentacea, hitherto regarded as a threatened species, in the north-western Mediterranean Sea. Mar. Pollut. Bull. 89, 305-323. doi: 10.1016/j.marpolbul.2014.09.043

Thibaut, T., Pinedo, S., Torras, X., and Ballesteros, E. (2005). Long-term decline of the populations of Fucales (Cystoseira spp. and Sargassum spp.) in the Albères coast (France, North-western Mediterranean). Mar. Pollut. Bull. 50, 1472-1489. doi: 10.1016/j.marpolbul.2005.06.014

Trigos, S., García-March, J. R., Vicente, N., Tena, J., and Torres, J. (2014). Utilization of muddy detritus as organic matter source by the fan mussel Pinna nobilis. Medit. Mar. Sci. 15, 667-674. 
Troell, M., Halling, C., Neori, A., Chopin, T., Buschmann, A. H., Kautsky, N., et al. (2003). Integrated mariculture: asking the right questions. Aquaculture 226, 69-90. doi: 10.1016/s0044-8486(03)00469-1

Turley, C. M. (1999). The changing Mediterranean Sea - A sensitive ecosystem? Prog. Oceanogr. 44, 387-400. doi: 10.1016/s0079-6611(99)00033-6

van Kan, J. A. L. (2006). Licensed to kill: the lifestyle of a necrotrophic plant pathogen. Trends Plant Sci. 11, 247-253. doi: 10.1016/j.tplants.2006.03.005

Vázquez-Luis, M., Álvarez, E., Barrajón, A., García-March, J. R., Grau, A., Hendriks, I. E., et al. (2017). S.O.S. Pinna nobilis: a mass mortality event in western Mediterranean Sea. Front. Mar. Sci. 4:20. doi: 10.3389/fmars.2017. 00220

Verlaque, M. (1987). "Relations entre Paracentrotus lividus (Lamarck) et le phytobenthos de Méditerranée occidentale," in Colloque International sur Paracentrotus lividus et les Oursins Comestibles, ed. C. F. Boudouresque (Marseille: GIS Posidonie Publications), 5-36.

Verlaque, M. (1994). Inventaire des plantes marines introduites en Méditerranée: origine et répercussions sur l'environnement et les activités humaines. Oceanol. Acta 17, 1-23.

Verlaque, M. (2001). Checklist of the macroalgae of Thau Lagoon (Hérault, France), a hot spot of marine species introduction in Europe. Oceanol. Acta 24, 29-49. doi: 10.1016/s0399-1784(00)01127-0

Verlaque, M., Boudouresque, C. F., and Mineur, F. (2007a). Impact of mariculture on coastal ecosystems, CIESM Workshop Monographs. 32, 39-47.

Verlaque, M., Boudouresque, C. F., and Mineur, F. (2007b). Oyster transfers: a major vector for macrophyte introductions. Rapp. P.V. Réun. Comm. int. Explor. Mer. Médit. 38:632.

Verlaque, M., Ruitton, S., Mineur, F., and Boudouresque, C. F. (2015). “CIESM atlas of exotic species," in 4 Macrophytes, ed. F. Briand (Monaco: CIESM Publisher), $1-362$.

Verneau, N., Thomassin, B. A., and Viale, D. (1995). Modifications de l'herbier de Posidonies et des populations de poissons dans l'ombre portée sur le fond par des radeaux aquacoles installés dans le golfe d'Ajaccio (Corse-du-Sud, Méditerranée nord-occidentale). J. Rech. Océanogr. 20, 33-41.

Vizzini, S., and Mazzola, A. (2004). Stable isotope evidence of the environmental impact of a land-based fish farm in the western Mediterranean. Mar. Pollut. Bull. 49, 61-70.

Volpe, M. G., Fabbrocini, A., Siano, F., Coccia, E., Scordella, G., Licchelli, C., et al. (2018). Gonad quality of sea urchin Paracentrotus lividus cultured in an offshore pilot-scale trial on the south-east Italian coast. Aquacult. Nutr. 24, 1444-1455.

Walls, A. M., Kennedy, R., Edwards, M. D., and Johnson, M. P. (2017). Impact of kelp cultivation on the Ecological Status of benthic habitats and Zostera marina biomass. Mar. Pollut. Bull. 124, 19-27.

Weitzman, J., Steeves, L., Bradford, J., and Filgueira, J. (2019). "Far-field and near-field effects of marine aquaculture," in World Seas: An Environmental Evaluation, ed. C. Sheppard (Amsterdam: Elsevier), 197-220.

Wolf, M. A., Buosi, A., Juhmani, A. S. F., and Sfriso, A. (2018). Shellfish import and hull fouling as vectors for new red algal introductions in the Venice Lagoon. Estuar. Coast. Shelf Sci. 215, 30-38.

Wrange, A. L., Valero, J., Harkestad, L. S., Strand, $\varnothing$, Lindegarth, S., Christensen, H. T., et al. (2010). Massive settlement of the Pacific oyster, Crassostrea gigas, in Scandinavia. Biol. Inv. 12, 1253-1258.

Yokoyama, H., Abo, K., Toyokawa, M., Toda, S., and Yamamoto, S. (1997). Impact of mariculture on the spatial and temporal patterns of the macrobenthos in Gokasho Bay. Bull. Natl. Res. Inst. Aquacult. Suppl. 3, 7-16.

Zeller, D., Booth, S., Craig, P., and Pauly, D. (2006). Reconstruction of coral reef fisheries catches in American Samoa, 1950-2002. Coral Reefs 25, $144-152$.

Zenetos, A., Koutsoubas, D., and Vardala-Theodorou, E. (2005). Origin and vectors of introduction of exotic molluscs in Greek waters. Belg. J. Zool. 135, 279-286.

Zupo, V., Glaviano, F., Paolucci, M., Ruocco, N., Polese, G., Di Cosmo, A., et al. (2019). Roe enhancement of Paracentrotus lividus: Nutritional effects of fresh and formulated diets. Aquacult. Nutr. 25, 26-38.

Conflict of Interest: The authors declare that the research was conducted in the absence of any commercial or financial relationships that could be construed as a potential conflict of interest.

Copyright (c) 2020 Boudouresque, Blanfuné, Pergent, Pergent-Martini, PerretBoudouresque and Thibaut. This is an open-access article distributed under the terms of the Creative Commons Attribution License (CC BY). The use, distribution or reproduction in other forums is permitted, provided the original author(s) and the copyright owner(s) are credited and that the original publication in this journal is cited, in accordance with accepted academic practice. No use, distribution or reproduction is permitted which does not comply with these terms. 